\title{
APT Blanket Safety Analysis: Preliminary Analyses of Downflow Through a Lateral Row 1 Blanket Model Under Near RHR Conditions
}

by

L. L. Hamm

Westinghouse Savannah River Company

Savannah River Site

Aiken, South Carolina 29808

S. Y. Lee

M. A. Shadday

F. G. Smith, III

A document prepared for SENDING TO LANL at , , from - .

DOE Contract No. DE-AC09-96SR18500

This paper was prepared in connection with work done under the above contract number with the $U$. S.

Department of Energy. By acceptance of this paper, the publisher and/or recipient acknowledges the U.S. Government's right to retain a nonexclusive, royalty-free license in and to any copyright covering this paper, along with the right to reproduce and to authorize others to reproduce all or part of the copyrighted paper. 


\section{DISCLAIMER}

Portions of this document may be illegible in electronic image products. Images are produced from the best available original document. 


\section{APT BLANKET SAFETY ANALYSIS: PRELIMINARY ANALYSES OF DOWNFLOW THROUGH A LATERAL ROW 1 BLANKET MODULE UNDER NEAR RHR CONDITIONS}

M. Andy Shadday

L. Larry Hamm

Frank G. Smith, III

Westinghouse Savannah River Company Savannah River Site Aiken, SC 29808

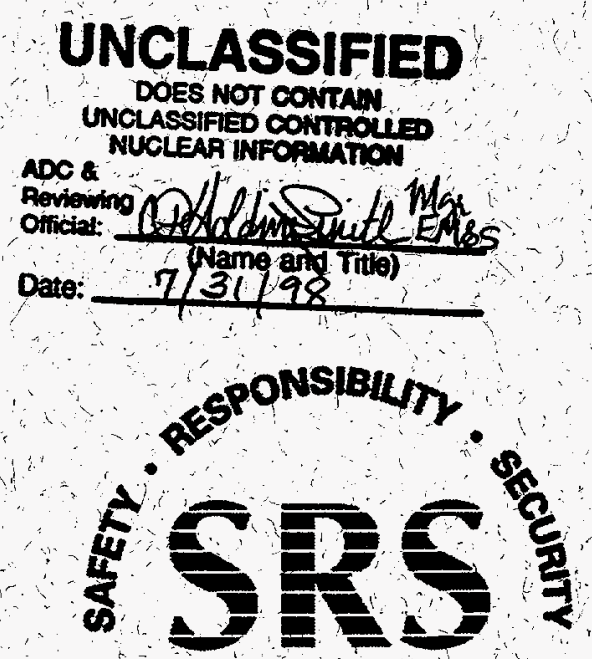




\section{DISCLAMER}

This report was prepared as an account of work sponsored by an agency of the United States Government. Neither the United States Government nor any agency thereof, nor any of their employees, makes any warranty, express or implied, or assumes any legal liability or responsibility for the accuracy, completeness, or usefulness of any information, apparatus, product, or process disclosed, or represents that its use would not infringe privately owned rights. Reference herein to any specific commercial product, process, or service by trade name, trademark, manufacturer, or otherwise does not necessarily constitute or imply its endorsement, recommendation, or favoring by the United States Government or any agency thereof. The views and opinions of authors expressed herein do not necessarily state or reflect those of the United States Government or any agency thereof.

This report has been reproduced directly from the best available copy.

Available to DOE and DOE contractors from the Office of Scientific and Technical Information, P.O. Box 62, Oak Ridge, TN 37831; prices available from (615) 576-8401.

Available to the public from the National Technical Information Service, U.S. Department of Commerce, 5285 Port Royal Road, Springfield, VA 22161. 
WSRC-TR-98-0163

KEYWORDS:

Accelerator Production of Tritium Blanket System

Conceptual Design FLOWTRAN-TF Code Module Model Safety Analysis

RETENTION - Permanent

\section{APT BLANKET SAFETY ANALYSIS: PRELIMINARY ANALYSES OF DOWNFLOW THROUGH A LATERAL ROW 1 BLANKET MODULE UNDER NEAR RHR CONDITIONS}

SAVANNAH RIVER TECHNOLOGY CENTER

M. Andy Shadday

L. Larry Hamm

Frank G. Smith, III

Publication Date: July, 1998

Westinghouse Savannah River Company

Savannah River Site

Aiken, SC 29808

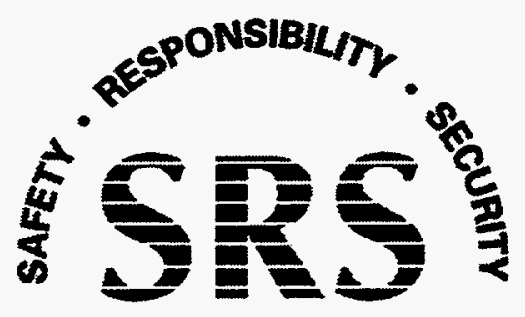

Prepared for the U.S. Department of Energy under Contract No. DE-AC09-96SR18500 
DOCUMENT: WSRC-TR-98-0163

TITLE: APT BLANKET SAFETY ANALYSIS:

PRELIMINARY ANALYSES OF DOWNFLOW THROUGH A LATERAL ROW 1 BLANKET MODULE UNDER NEAR RHR CONDITIONS

APPROVALS
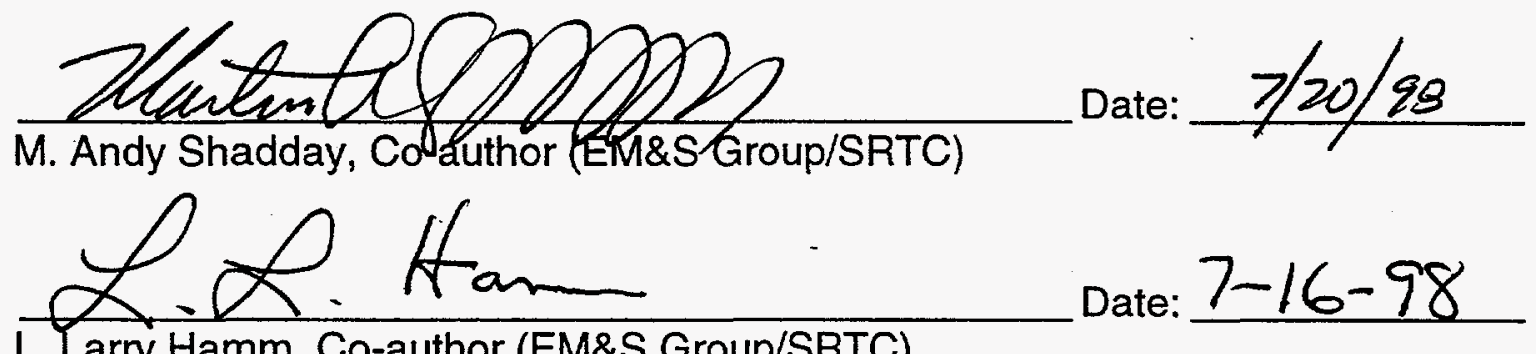

L. Larry Hamm, Co-author (EM\&S Group/SRTC)

Date: $7-16-98$

Zraak 11 smettid

Frank G. Smith, III, Co-author (PC\&C Group/SRTC)

Date:
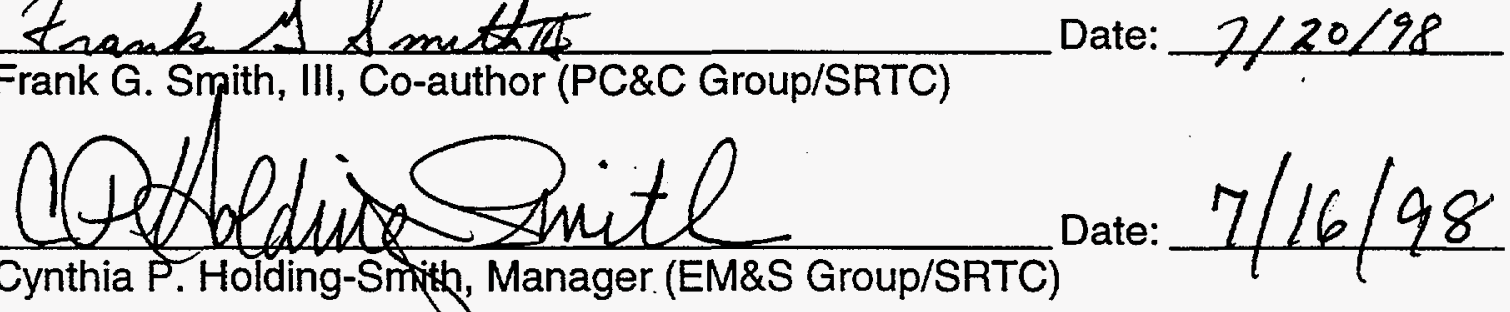

m.Q:EAra

Martha A. Ebra, Manager (EDS/SRTC)
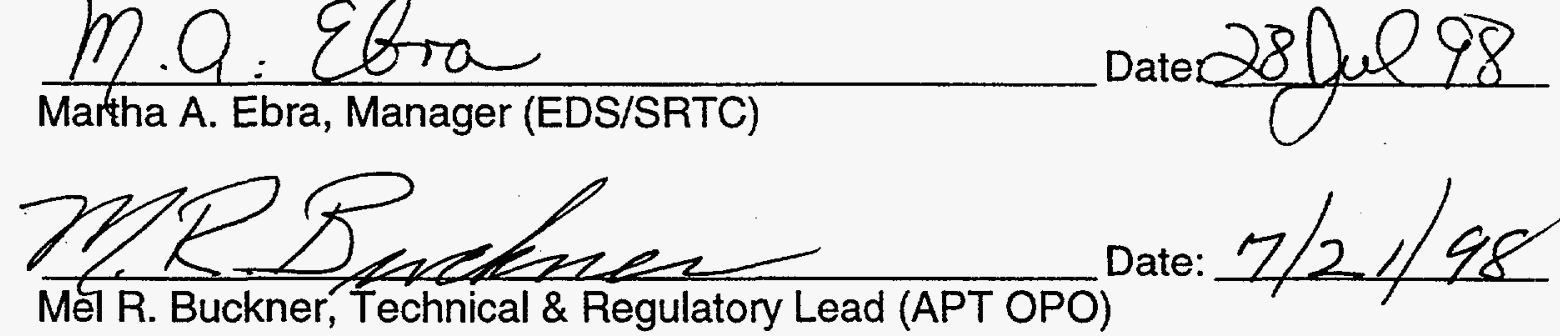

The internal technical review function is being performed at the APT project level and is coordinated through LANL. 


\section{Table of Contents}

1 Summary

2 Background 1

3 Two Channel Analytical Model 2

4 Eleven Channel FLOWTRAN-TF Model 4

5 Discussion and Results 4

6 Conclusions 5

7 References 5

Appendix A: Derivation of the Governing Equations for Mixed Convection Downflow through the Lumped TwoChannel APT Blanket Module

Appendix B: FLOWTRAN-TF Input File for Front Lateral Row-1 Bin (downflow and upflow under near RHR conditions) 
Figure 1

Figure 2

Figure 3

Figure 4

Figure 5

Figure 6

Figure 7

Figure 8

Figure 9

Figure 10

Figure 11

Figure A-1

Figure A-2

Table 1

Table 2

Table 3

Table 4

Table 5

\section{List of Figures}

Schematic of the mixed convection two-channel network with differentially heated channels. 7

Flow splits in the heated two-channel network ......................................8

Plan view of FLOWTRAN-TF 11 channel model of front lateral

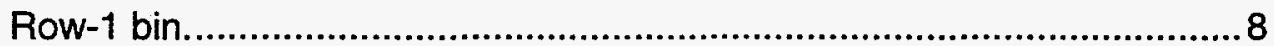

Axial power shape for front lateral Row-1 bin. .......................................

Lateral power shape for front lateral Row-1 bin.......................................

Power shape parallel with beam for front lateral Row-1 bin.................... 10

FLOWTRAN-TF channel 1 and 11 mass flow fractions for front

lateral Row-1 bin at 1\% power and near RHR flow conditions for

the net downflow case.

FLOWTRAN-TF inlet plenum pressure for front lateral Row-1 bin

at $1 \%$ power and near RHR flow conditions for the net downflow

case.

3-D perspective of FLOWTRAN-TF 11 channel model of front

lateral Row- 1 bin (temperature profile under RHR conditions for

the net downflow case included).

FLOWTRAN-TF channel 1 and 11 mass flow fractions for front

lateral Row-1 bin at 1\% power and near RHR flow conditions for

the net upflow case.

FLOWTRAN-TF top plenum pressure for front lateral Row-1 bin at

$1 \%$ power and near RHR flow conditions for the net upflow case.

A differential section of a channel with downflow, showing the

applied surface and body forces.

A differential section of the higher power channel with upflow,

showing the applied surface and body forces.

\section{List of Tables}

FLOWTRAN-TF solid material thermal properties used for

modeling front lateral Row-1 bin.

FLOWTRAN-TF channel mass flow fractions for front lateral Row-

1 bin at $1 \%$ power and near RHR flow conditions for the net

downflow case (a negative number implies an upflow condition)

FLOWTRAN-TF inlet/outlet plenum pressures for front lateral

Row-1 bin at $1 \%$ power and near RHR flow conditions for the net

downflow case.

FLOWTRAN-TF channel mass flow fractions for front lateral Row-

1 bin at $1 \%$ power and near RHR flow conditions for the net

upflow case (a positive number implies an upflow condition).

FLOWTRAN-TF top/bottom plenum pressures for front lateral

Row- 1 bin at $1 \%$ power and near RHR flow conditions for the net

upflow case. 


\section{Summary}

To address a concern about a potential maldistribution of coolant flow through an APT blanket module under low flow near RHR conditions, a scoping study of downflow mixed convection in parallel channels was conducted. Buoyancy will adversely effect the flow distribution in module bins with downflow and non-uniform power distributions. This study consists of two parts: a simple analytical model of flow in a two channel network, and a lumped eleven channel FLOWTRAN-TF [Ref. 1] model of a front lateral Row-1 blanket module bin. Results from both models indicate that the concern about coolant flow in a vertical module being diverted away from high power regions by buoyancy is warranted. The FLOWTRAN-TF model predicted upflow (i.e., a flow reversal) through several of the high power channels, under some low flow conditions. The transition from the regime with downflow in all channels to a regime with upflow in some channels was abrupt.

Regardless of the direction of net mass flow through a module bin (i.e., net downflow or upflow), a non-uniform horizontal power distribution will result in non-uniform mass fluxes, for sufficiently low net mass flowrates. Under net downflow conditions a noticeable overall increase in hydraulic losses is observed. Consequently, it is recommended that the modules with vertical flow be designed with upflow through the higher power bins. This will minimize the adverse impact of buoyancy.

\section{Background}

For cooling purposes, adjacent blanket module bins are grouped together in pairs with coolant flowing sequentially through the two bins, down through the first and up through the second. Each bin has numerous discrete flow channels that are connected to common inlet and outlet plenums. Under normal operating conditions, the coolant can potentially be more efficiently utilized if it first flows through the higher power bin in the module. This could allow an increase in the lead to water ratio in the higher power modules, and therefore an increase in tritium production efficiency due to lower temperature water flowing through the high power bin. However, the downside to this design modification is, for the lateral blanket modules, the flow direction is opposite to that which would occur due to buoyancy. During normal operation this should not be a problem because the forced convection overwhelms the influence of buoyancy, but at low flow conditions buoyancy can significantly influence the flow distribution within a bin. Flow is partially diverted from the high to the low power region. A second effect is the partial diversion of flow from high power vertical modules to horizontal modules above and below the target and lower power vertical modules. These two adverse effects are complementary. The higher power vertical blanket modules will have proportionally more flow diverted away, and reducing the downflow through a vertical module aggravates the buoyancy induced maldistribution of flow within a bin with downflow. The buoyancy induced diversion of flow within the front lateral Row-1 module bin is considered in this study. There is a sevenfold increase in deposited power in the beamwise direction within this bin.

This study consists of two analyses, described in the next two sections of this document, that were completed sequentially. The first is a simple analytical model of mixed convection downflow through a two parallel channel network. The second is an eleven 
channel numerical model of downflow through a front lateral Row-1 bin. The overall conclusions/results are based on the numerical model and are presented in Sections 5 and 6 below. The reader may skip the following discussion on the analytic model contained within Section 3 (and its development in Appendix A) without a loss of continuity with regard to the results and conclusions.

\section{Two Channel Analytical Model}

As an initial step towards quantifying the effect of non-uniform heating on the distribution of downflow through a vertical blanket module, a simple system with two parallel channels was considered. Figure 1 is a schematic of a mixed convection network with downflow through the parallel heated channels. The two channels are geometrically similar, but they are heated differentially, each with uniform heating along its length. Incompressible steady flow with a Boussinesq fluid and well mixed top and bottom plenums are assumed. Flow regimes with downflow through both channels and upflow through the high power channel are considered. The net mass flowrate through the network is specified, and the analytical model predicts the flow split. Equation 1 is the non-dimensional momentum equation for the network with downflow through both channels. This equation is derived in Appendix A.

$$
2\left(\dot{m}^{*}\right)^{3}-3\left(\dot{m}^{*}\right)^{2}+\left(1+\frac{G r}{f \operatorname{Re}^{2}}\right) \dot{m}^{*}-\frac{G r}{f \operatorname{Re}^{2}} \dot{Q}^{*}=0
$$

where

$$
\dot{m}^{*}=\frac{\dot{m}_{1}}{\dot{m}} \& \quad \dot{Q}^{*}=\frac{\dot{Q}_{1}}{\dot{Q}}
$$

and

$$
G r=\frac{g \beta D^{3} \Delta T}{v^{2}} \quad \operatorname{Re}=\frac{\rho V D}{\mu}
$$

The value of the Archimedes number, the non-dimensional grouping with the Grashoff number in the numerator and the product of the friction factor and square of the Reynolds number in the denominator, is a measure of the relative importance of buoyancy and forced convection to the flow. The relative importance of buoyancy is directly proportional to the value of this parameter. Channel 1 is assumed to have the higher deposited power of the two channels, and it has the lower flowrate of the two. If the power split between the two channels is equal then the flow split is equal, irrespective of the value of the Archimedes number. Figure 2 is a plot of the flow splits as functions of the power split and the Archimedes number. Results for six different values of the Archimedes number are presented. The dotted line in Fig. 2 is the limit below which steady-state solutions with downflow through both channels do not exist. For values of the Archimedes number greater than 0.1 , there is a maximum value of the power split ratio above which steady-state flows in this flow regime do not exist. The limiting power split ratio decreases as the value of the Archimedes number increases. 
Equation 2 is the momentum equation for the case in which steady-state upflow through the higher power channel is assumed. This equation is also derived in Appendix $A$, and solutions are presented in Fig. 2.

$$
2\left(\dot{m}^{*}\right)^{4}+4\left(\dot{m}^{*}\right)^{3}+3\left(\dot{m}^{*}\right)^{2}+\left(1-\frac{G r}{f \operatorname{Re}^{2}}\right) \dot{m}^{*}-\frac{G r}{f \operatorname{Re}^{2}} \dot{Q}^{*}=0
$$

Since upflow in channel one was assumed in the derivation of eq. 2 , the mass flowrate ratio is positive. In Fig. 2 these ratios are plotted as negative to distinguish them from solutions to eq. 1, (i.e., downflow through both channels). Cases with the same Archimedes number are shown in Fig. 2 with the same symbols, irrespective of the flow direction in channel one. For a specified Archimedes number, the flow regime transitions abruptly from downflow through both channels to that with upflow through channel one once the limiting value of the power split, shown by the dotted line in the figure, is exceeded.

During normal operation, the flow through a lateral Row-1 bin has a Reynolds number of approximately 18,000 [Ref. 2]. At four percent flow, the capacity of a single RHR system, the Reynolds number would be 720, and at one percent flow it becomes 180 . With the following assumed values for the parameters in the Grashoff and Reynolds numbers, and using the laminar pipe flow expression for the Darcy friction factor, the two values for the Archimedes number are 0.055 and 0.22 for four and one percent of normal operation flow respectively:

$$
\begin{gathered}
D_{h} \approx 0.005 \mathrm{~m} \\
\Delta T \approx 5^{\circ} \mathrm{C} \\
\beta=0.000181 / \mathrm{K} \\
v=6.58 \times 10^{-7} \mathrm{~m}^{2} / \mathrm{s}
\end{gathered}
$$

While the predicted buoyancy induced flow diversion is small at the designed RHR flowrate of four percent, this flowrate is uncomfortably close to the region where the flow diversion becomes significant and reverse flow in the high power channels is possible. The concern about downflow through the high power blanket bins is warranted. The numerous simplifying assumptions in this scoping model limit the quantitative value of the results, but they do have qualitative value and suggest that further study is necessary. To this end, the FLOWTRAN-TF model of a front lateral Row-1 module bin, described in the next section, was developed.

\section{Eleven Channel FLOWTRAN-TF Model}

A front lateral Row- 1 module bin has 44 plates and 308 discrete parallel flow passages. These channels were lumped into eleven geometrically similar rectangular channels in the FLOWTRAN-TF model of an entire bin. Figure 3 is a drawing of a horizontal crosssection of the model, showing the eleven channels and the finite-element grid of the solid heat structure. The solid region and channels are discretized into ten axial cells. Each of the eleven lumped channels has a flow area of $19.48 \mathrm{~cm}^{2}$ and a hydraulic diameter $0.47 \mathrm{~cm}$. Values for these channel parameters were estimated from a 
schematic of a lateral Row-1 plate in Ref. 1. Each of the rectangular channels shown in Fig. 3 has a cross-sectional area of $44.12 \mathrm{~cm}^{2}$. This represents the cross-sectional area of the 28 flow channels associated with four plates and also the associated helium tubes. The solid region in the model represents the volume of lead and aluminum associated with the 44 plates in the bin. The channel flow areas and hydraulic diameters are specified in the input file, and they do not have to be geometrically consistent with the discretization of the solid region. Table 1 lists thermal properties for the solid region. Since the solid region represents a homogenization of discrete lead plates that are clad with aluminum, it is anisotropic and different values are used for the vertical and horizontal thermal conductivities.

Figures 4 through 6 show the axial, lateral, and beamwise profiles for the relative deposited lead power in the solid region of the model [Ref. 2], respectively. The power varies by approximately a factor of seven in the beamwise direction. This power distribution influences the flow distribution among the eleven channels. All of the results shown have a total deposited power of $33.96 \mathrm{~kW}$, one percent of nominal power.

The specified flow boundary conditions are the inlet volume flowrate and the bottom plenum pressure. These are time independent, and a false transient was run until convergence to steady-state was achieved. Cases were run with flowrates between 0.5 and $8.0 \%$ of full flow $\left(0.09036 \mathrm{~m}^{3} / \mathrm{s}\right)$.

\section{$5 \quad$ Discussion and Results}

Figure 7 shows the channel mass flow fractions in channels 1 and 11 for net downflow through the bin with flowrates between $0.75 \%$ and $6.0 \%$ of normal flow. Channel 1 is the front channel of the bin in the beamwise direction and the channel through the lowest power region. Channel 11 is the back channel and the one through the highest power region. The total deposited power is $1 \%$ of normal power in all cases. The flow fractions for all of the channels are listed in Table 2. The flow distribution is uniform above $4 \%$ flow, and flow is partially diverted through the lower power channels below this value. At approximately $1.25 \%$ flow, the flow regime abruptly transitions to one in which there is upflow through the high power channels. Figure 8 shows the inlet plenum pressures with net downflow through the bin and flowrates between $0.75 \%$ and $4.0 \%$ of normal flow. The outlet plenum pressure is held constant at $584 \mathrm{kPa}$. Also shown are results where the power distribution in the beamwise direction is uniform. This figure shows the influence of the beamwise power distribution on the overall bin frictional pressure drop. This influence is discernible at flows below $2 \%$, and it abruptly becomes very significant when upflow occurs in the high power channels. This is a phenomena that would not be predicted in a system model where a module is represented by a single 1-D channel. Table 3 lists the inlet and outlet plenum pressures. Figure 9 shows a 3-D perspective view of the temperature distribution in the solid region of the bin for the case with $4 \%$ flow.

Figure 10 shows the channel mass flow fractions in channels 1 and 11 for net upflow through the bin with flowrates between $0.75 \%$ and $8.0 \%$ of normal flow. The deposited power is $1 \%$ of normal power in all cases. The flow fractions for all of the channels are listed in Table 4. The flow distribution is non-uniform and flow is partially diverted through the high power channels below $8 \%$ of normal flow. Figure 11 shows the top or outlet plenum pressures with net upflow through the module and flowrates between $0.5 \%$ and $4.0 \%$ of normal flow. The bottom plenum pressure is held constant at 584 
$\mathrm{kPa}$. Also shown are results where the power distribution in the beamwise direction is uniform. The influence of the power distribution is discernible at flows below $0.75 \%$. Table 5 lists the inlet and outlet plenum pressures.

\section{Conclusions}

From a safety analysis standpoint, configuring the coolant flowpaths through the blanket modules such that there is downflow through the highest power bins is not a good practice. While the coolant maldistribution in a front lateral Row-1 bin at the design RHR flowrate of $4 \%$ of normal flow is not severe, the point where reverse flow can occur in the highest power channels is uncomfortably close. The buoyancy induced diversion of flow between modules will reduce the RHR flow through the high power modules below design levels and can aggravate the flow maldistributions within the bins.

In addition to the potential adverse physical impact of downflow on the thermal-hydraulic performance of the RHR system, the safety analysis is further complicated. A 1-D TRAC system model, which lumps all of the channels in a bin into a single equivalent channel, will not capture the non-uniform flow distribution phenomena and increased hydraulic losses. Therefore, it would not produce appropriate boundary conditions for a detailed FLOWTRAN-TF model of a "hot" plate within a bin and its associated flow channels. Either the TRAC system model or the FLOWTRAN-TF model would have to be considerably more complicated, or an intermediate model that captures the flow distribution would be required.

Long term cooling under unmitigated event sequences uses natural circulation to transfer deposited power outside of the cavity vessel. Configuring the higher power bins in downflow adversely impacts natural circulation, at least during the early phase of an accident before a global flow reversal occurs.

\section{References}

1. L. L. Hamm, S. Y. Lee, M. A. Shadday, and F. G. Smith, III, "APT Blanket Detailed Bin Model Based on Initial Plate-Type Design - 3-D FLOWTRAN-TF Model," Westinghouse Savannah River Company, WSRC-TR-98-0055 (July 1998).

2. R. Kapernick, "APT Blanket Design," Los Alamos National Laboratory APT Safety Meeting, slide presentation (March, 31, 1988).

Table 1 FLOWTRAN-TF solid material thermal properties used for modeling front lateral Row-1 bin.

\begin{tabular}{|c|c|c|c|}
\hline 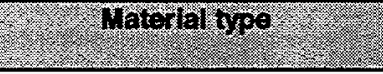 & $\begin{array}{l}\text { Densty } \\
\text { (kcim) }\end{array}$ & Spectilc hort & $\begin{array}{c}\text { Themal conoldoryty } \\
\text { Wming }\end{array}$ \\
\hline pure aluminum & 2713.0 & 925.0 & 171.0 \\
\hline pure lead & 11340.0 & 132.3 & 32.5 \\
\hline Row-1 mixture average & $\begin{array}{r}10123.0 \\
\text { (volume) }\end{array}$ & $\begin{array}{c}162.2 \\
\text { (volume) }\end{array}$ & $\begin{array}{l}48.0 \text { (horizontal) } \\
52.0 \text { (vertical) }\end{array}$ \\
\hline 11 channel effective values & 10123.0 & 162.2 & 79.1 \\
\hline
\end{tabular}


Table 2 FLOWTRAN-TF channel mass flow fractions for front lateral Row- 1 bin at $1 \%$ power and near RHR flow conditions for the net downflow case (a negative number implies an upflow condition).

\begin{tabular}{|c|c|c|c|c|c|c|c|c|c|c|c|}
\hline $\begin{array}{l}9 \% \\
10 w\end{array}$ & $\begin{array}{c}c m \\
1\end{array}$ & $\frac{c h n}{2}$ & $\frac{\mathrm{chm}}{3}$ & $\begin{array}{c}\text { chin } \\
4\end{array}$ & chm & $\frac{917}{6}$ & chr & $\begin{array}{c}\text { chm } \\
8\end{array}$ & $\begin{array}{c}\mathrm{csin} \\
9\end{array}$ & $\frac{c h \mathrm{p}}{10}$ & $\mathrm{chin}_{1}$ \\
\hline 0.75 & 0.140 & 0.137 & 0.133 & 0.129 & 0.123 & 0.113 & 0.077 & -0.033 & -0.038 & -0.038 & -0.038 \\
\hline 1.0 & 0.126 & 0.123 & 0.119 & 0.116 & 0.112 & 0.108 & 0.102 & 0.089 & 0.035 & -0.034 & -0.036 \\
\hline 1.25 & 0.109 & 0.106 & 0.103 & 0.099 & 0.095 & 0.091 & 0.087 & 0.083 & 0.079 & 0.076 & 0.073 \\
\hline 1.5 & 0.101 & 0.100 & 0.097 & 0.095 & 0.093 & 0.090 & 0.088 & 0.086 & 0.084 & 0.083 & 0.082 \\
\hline 2.0 & 0.096 & 0.095 & 0.093 & 0.092 & 0.091 & 0.090 & 0.090 & 0.089 & 0.088 & 0.088 & .088 \\
\hline 3.0 & 0.092 & 0.092 & 0.092 & 0.091 & 0.091 & 0.091 & 0.091 & 0.090 & 0.090 & 0.090 & 0.090 \\
\hline 4.0 & 0.091 & 0.091 & 0.091 & 0.091 & 0.091 & 0.091 & 0.091 & 0.091 & 0.091 & 0.091 & 0.091 \\
\hline 6.0 & 0.091 & 0.091 & 0.091 & 0.091 & 0.091 & 0.091 & 0.091 & 0.091 & 0.091 & 0.091 & 0.091 \\
\hline
\end{tabular}

Table 3 FLOWTRAN-TF inlet/outlet plenum pressures for front lateral Row-1 bin at $1 \%$ power and near RHR flow conditions for the net downflow case.

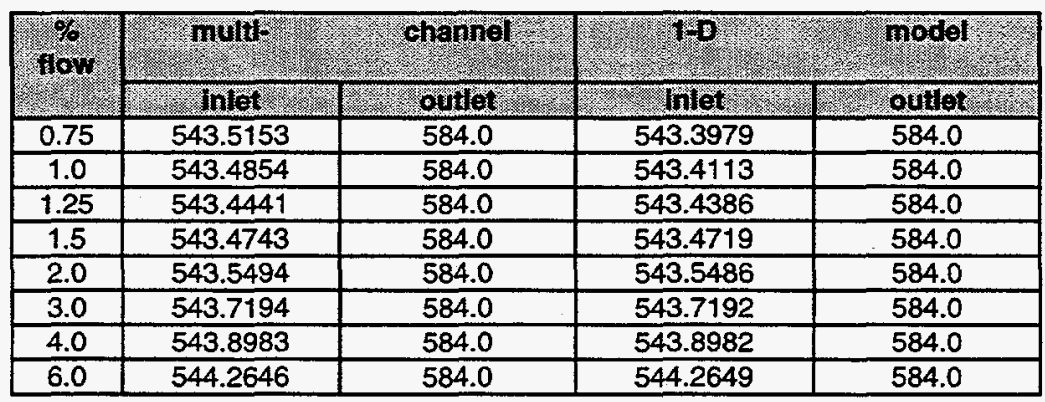

Table 4 FLOWTRAN-TF channel mass flow fractions for front lateral Row-1 bin at $1 \%$ power and near RHR flow conditions for the net upflow case (a positive number implies an upflow condition).

\begin{tabular}{|c|c|c|c|c|c|c|c|c|c|c|c|}
\hline $\begin{array}{l}\% \% \\
\text { floy } \\
\end{array}$ & $\mathrm{cm}$ & 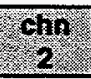 & $\frac{c h}{s}$ & chn & on & chin & $\frac{0 i n}{7}$ & $\frac{\mathrm{chr}}{8}$ & 80 & $\begin{array}{c}0110 \\
10\end{array}$ & $\frac{017}{11}$ \\
\hline 0.5 & 0.048 & 0.057 & 0.067 & 0.078 & 0.089 & 0.097 & 0.104 & 0.110 & 0.114 & 0.117 & 0.119 \\
\hline 0.75 & 0.053 & 0.063 & 0.074 & 0.083 & 0.091 & 0.097 & 0.102 & 0.106 & 0.109 & 0.111 & 0.113 \\
\hline 1.0 & 0.064 & 0.071 & 0.078 & 0.085 & 0.091 & 0.095 & 0.099 & 0.102 & 0.104 & 0.106 & 0.107 \\
\hline 2.0 & 0.081 & 0.084 & 0.086 & 0.089 & 0.091 & 0.092 & 0.094 & 0.095 & 0.096 & 0.096 & 0.097 \\
\hline 3.0 & 0.086 & 0.087 & 0.088 & 0.090 & 0.091 & 0.092 & 0.092 & 0.093 & 0.093 & 0.094 & 0.094 \\
\hline 4.0 & 0.088 & 0.088 & 0.089 & 0.090 & 0.091 & 0.091 & 0.092 & 0.092 & 0.093 & 0.093 & 0.093 \\
\hline 6.0 & 0.089 & 0.090 & 0.090 & 0.090 & 0.091 & 0.091 & 0.091 & 0.092 & 0.092 & 0.092 & 0.092 \\
\hline 8.0 & 0.091 & 0.091 & 0.091 & 0.091 & 0.091 & 0.091 & 0.091 & 0.091 & 0.091 & 0.091 & 0.091 \\
\hline
\end{tabular}


APT BLANKET SAFETY ANALYSIS:

Section:

1

(DOWNFLOW THROUGH A FRONT LATERAL ROW-1 MODULE)

Date:

$07 / 29 / 98$

Table 5 FLOWTRAN-TF top/bottom plenum pressures for front lateral Row- 1 bin at $1 \%$ power and near RHR flow conditions for the net upflow case.

\begin{tabular}{|c|c|c|c|c|}
\hline $\begin{array}{l}\% \% \\
10 \%\end{array}$ & $\sqrt{\mathrm{m}}$ & channey & 18 & mores \\
\hline 10 & $20 \mathrm{top}$ & (T.6tom & top & 160160m \\
\hline 0.5 & 543.2555 & 584.0 & 543.2098 & 584.0 \\
\hline 0.75 & 543.1427 & 584.0 & 543.1371 & 584.0 \\
\hline 1.0 & 543.0670 & 584.0 & 543.0679 & 584.0 \\
\hline 2.0 & 542.8368 & 584.0 & 542.8376 & 584.0 \\
\hline 3.0 & 542.6349 & 584.0 & 542.6352 & 584.0 \\
\hline 4.0 & 542.4401 & 584.0 & 542.4402 & 584.0 \\
\hline 6.0 & 542.0581 & 584.0 & 542.0582 & 584.0 \\
\hline 8.0 & 541.4704 & 584.0 & 541.4704 & 584.0 \\
\hline
\end{tabular}

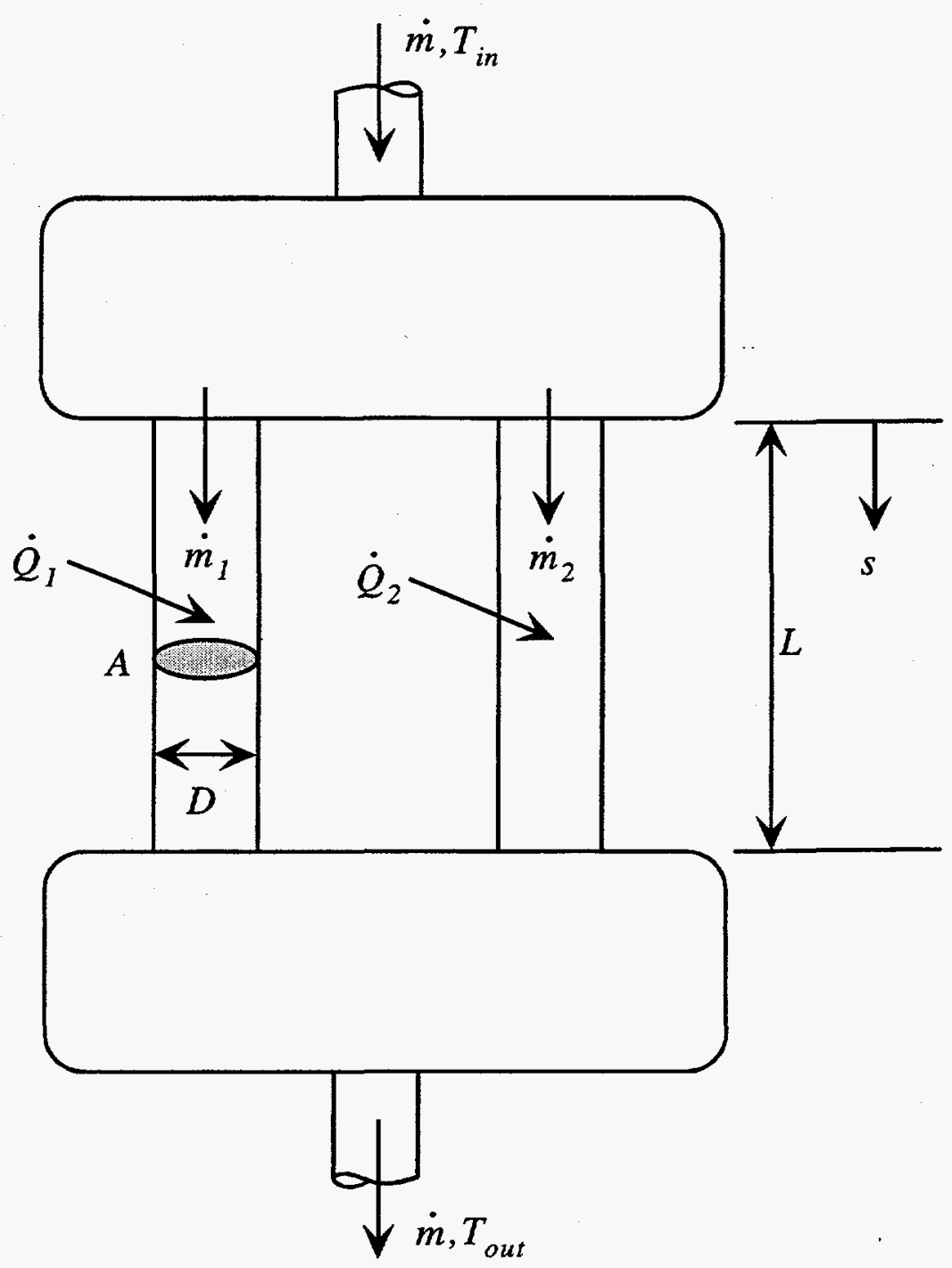

Figure 1 Schematic of the mixed convection two-channel network with differentially heated channels. 


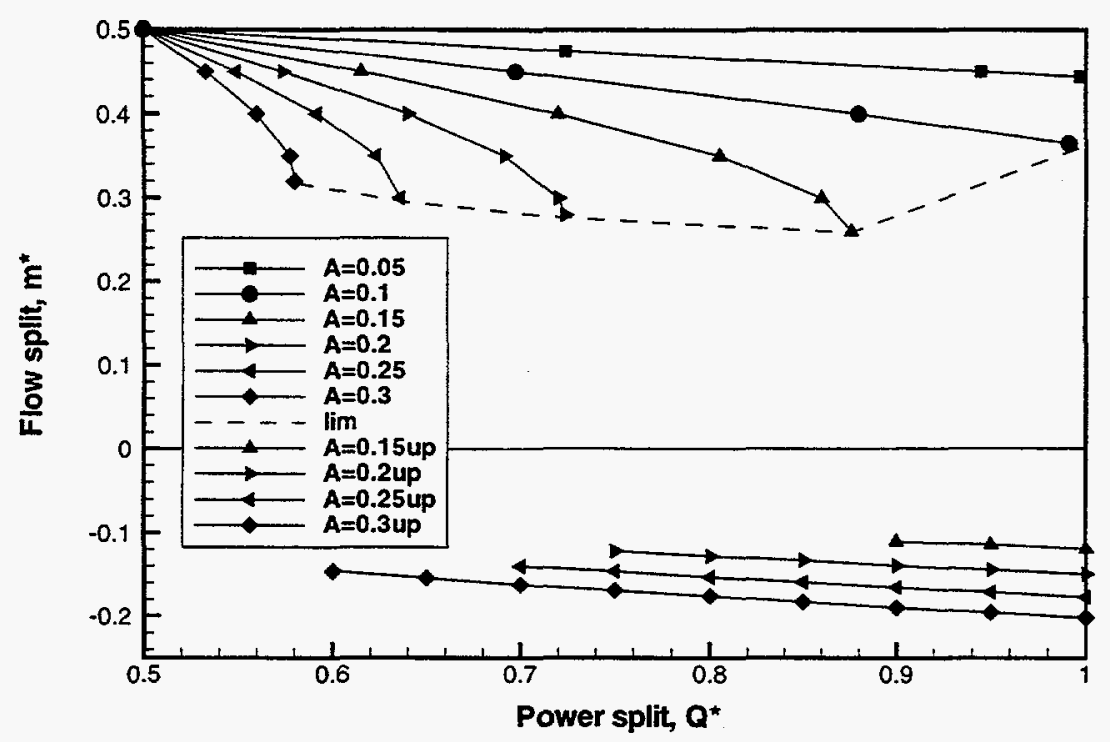

Figure 2 Flow splits in the heated two-channel network.

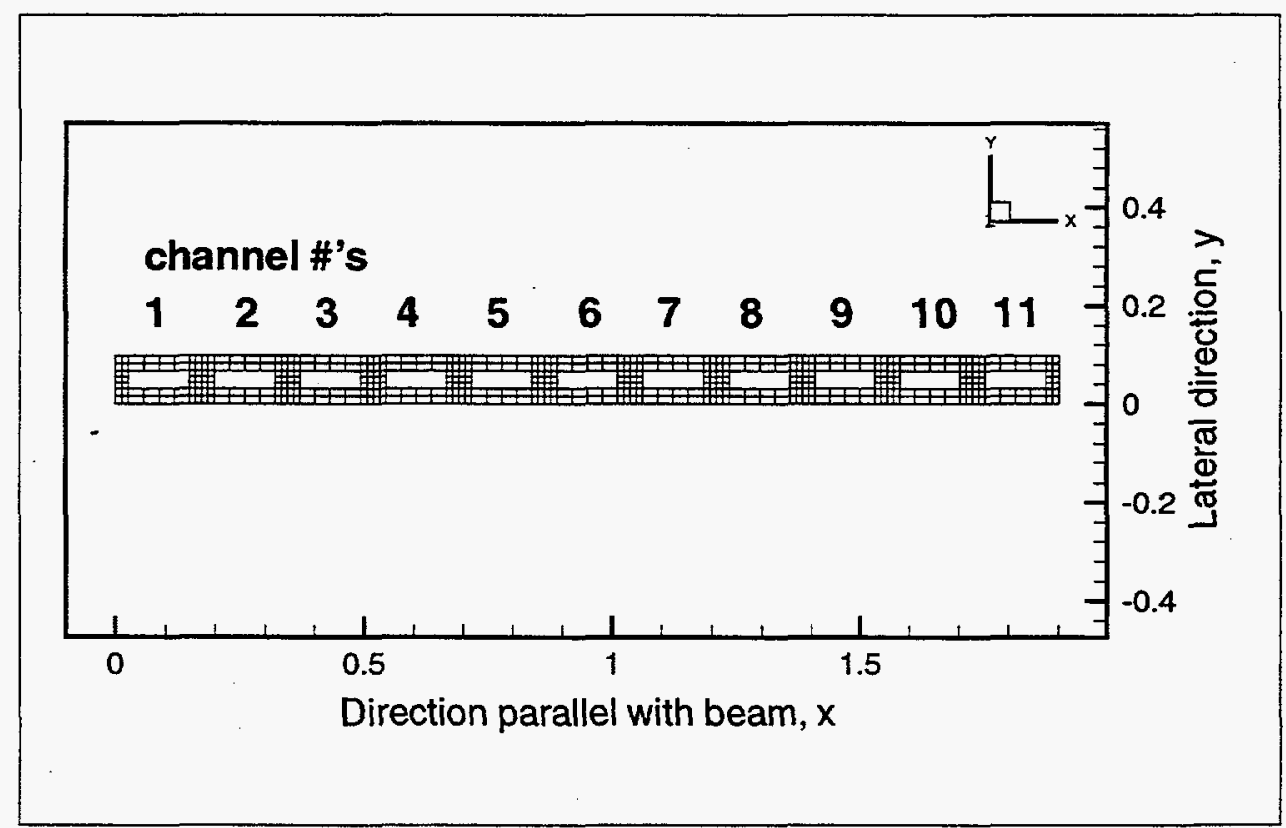

Figure 3 Plan view of FLOWTRAN-TF 11 channel model of front lateral Row-1 bin. 


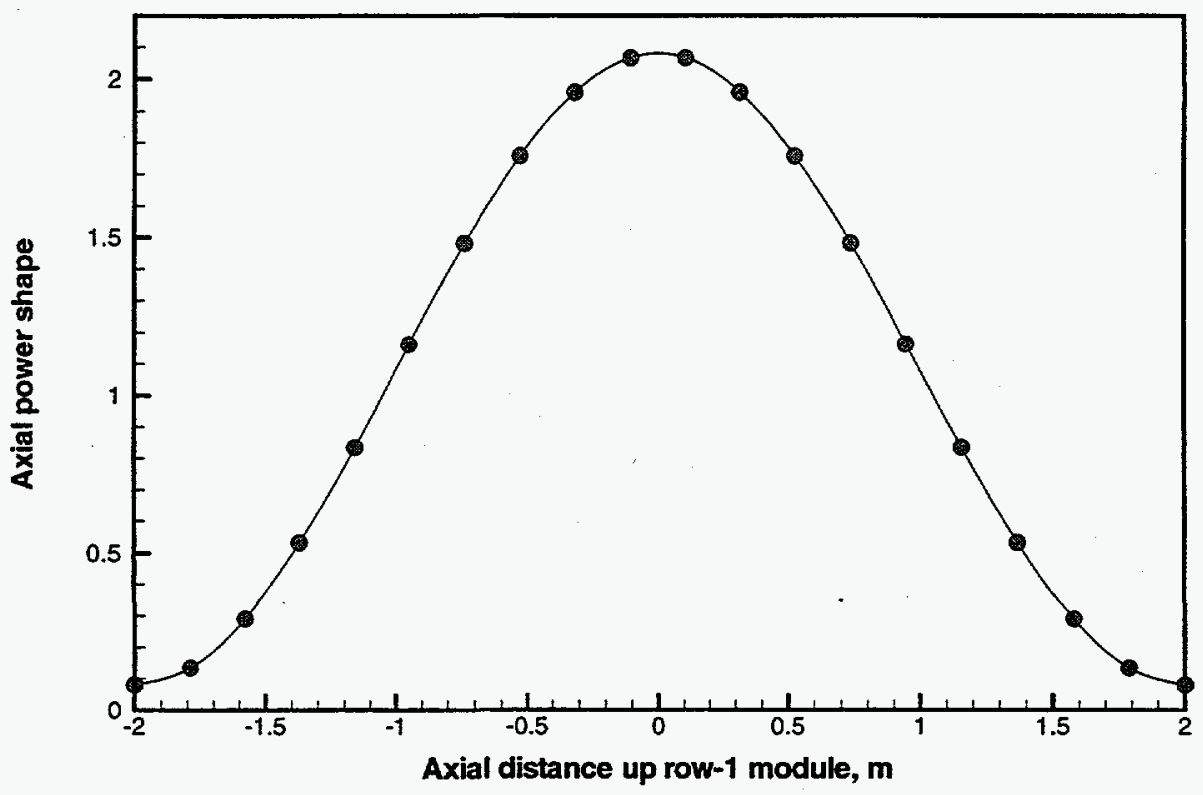

Figure 4 Axial power shape for front lateral Row-1 bin.

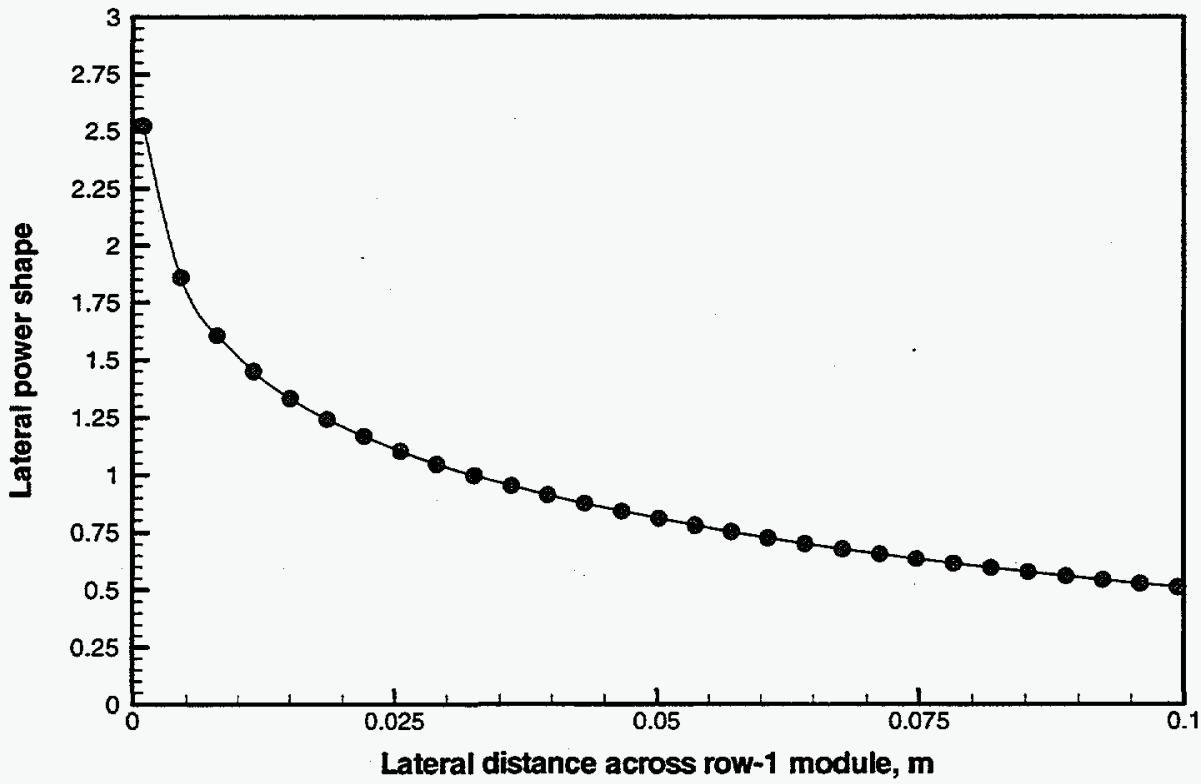

Figure 5 Lateral power shape for front lateral Row-1 bin. 


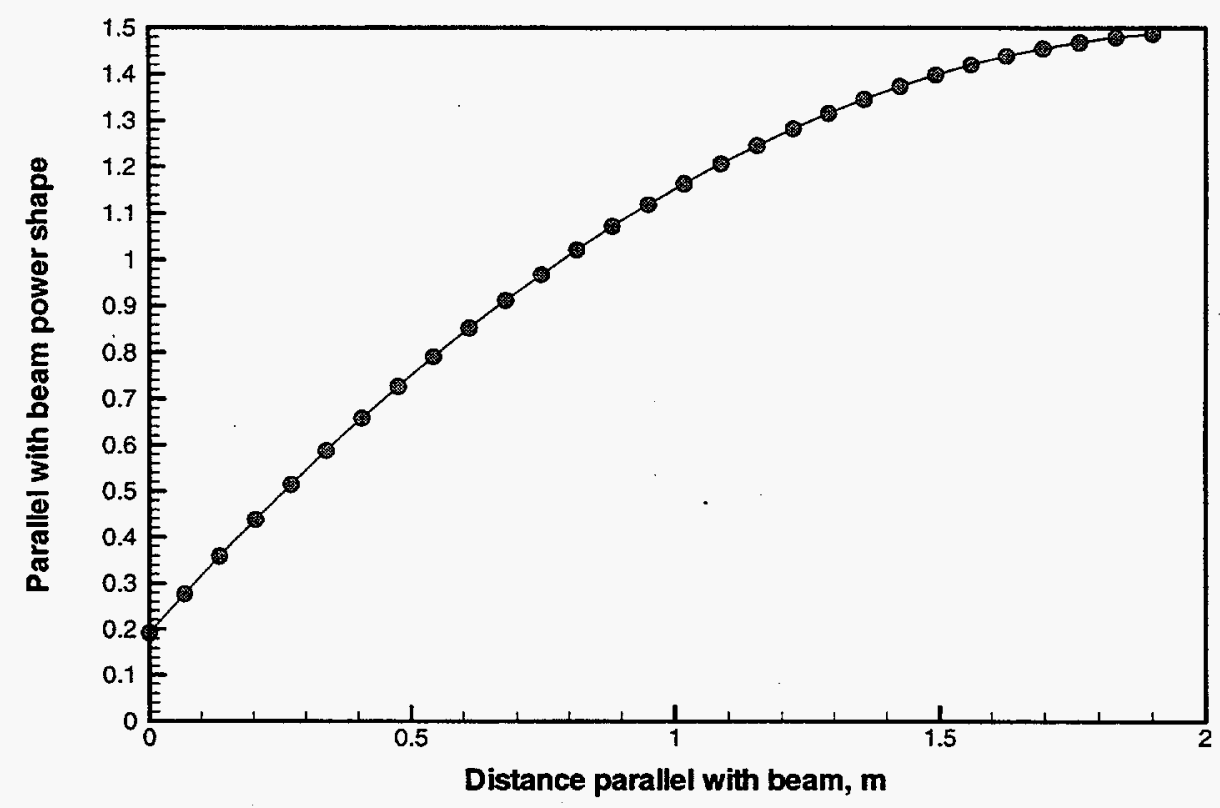

Figure 6 Power shape parallel with beam for front lateral Row-1 bin.

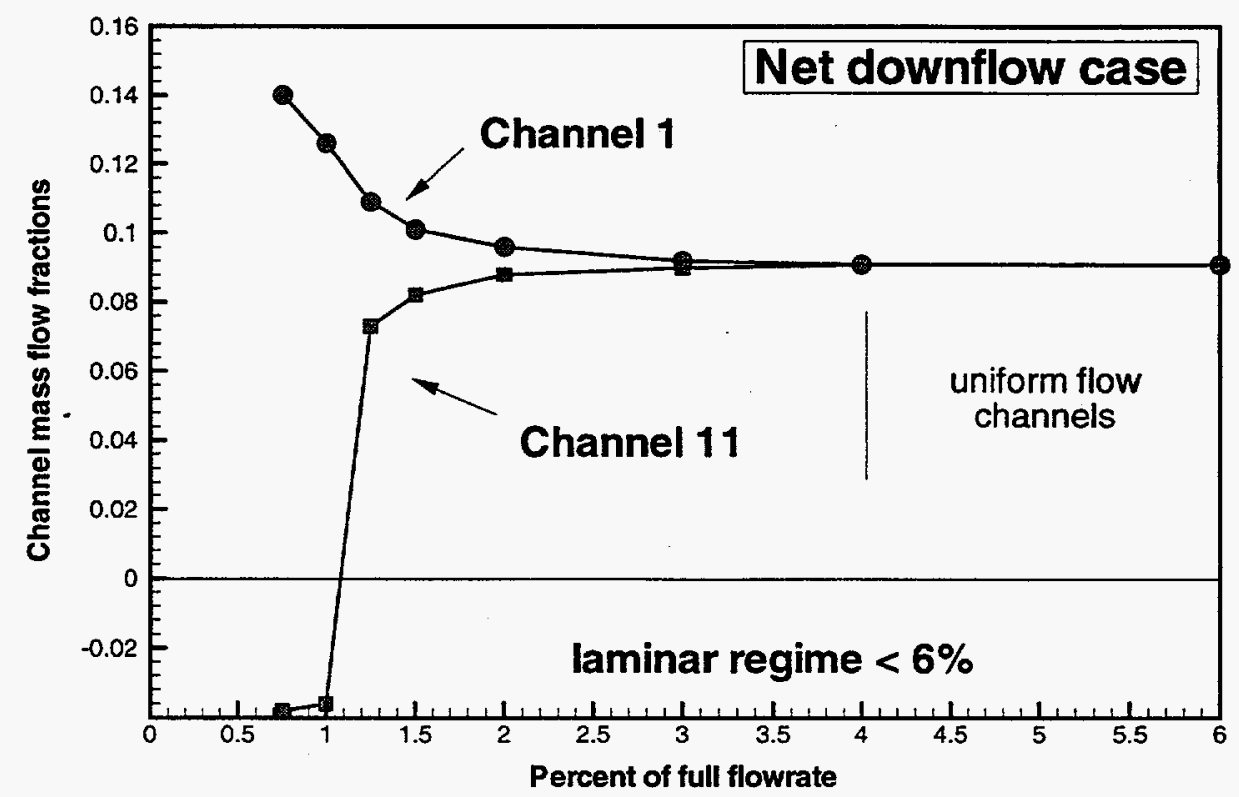

Figure 7 FLOWTRAN-TF channel 1 and 11 mass flow fractions for front lateral Row- 1 bin at $1 \%$ power and near RHR flow conditions for the net downflow case. 


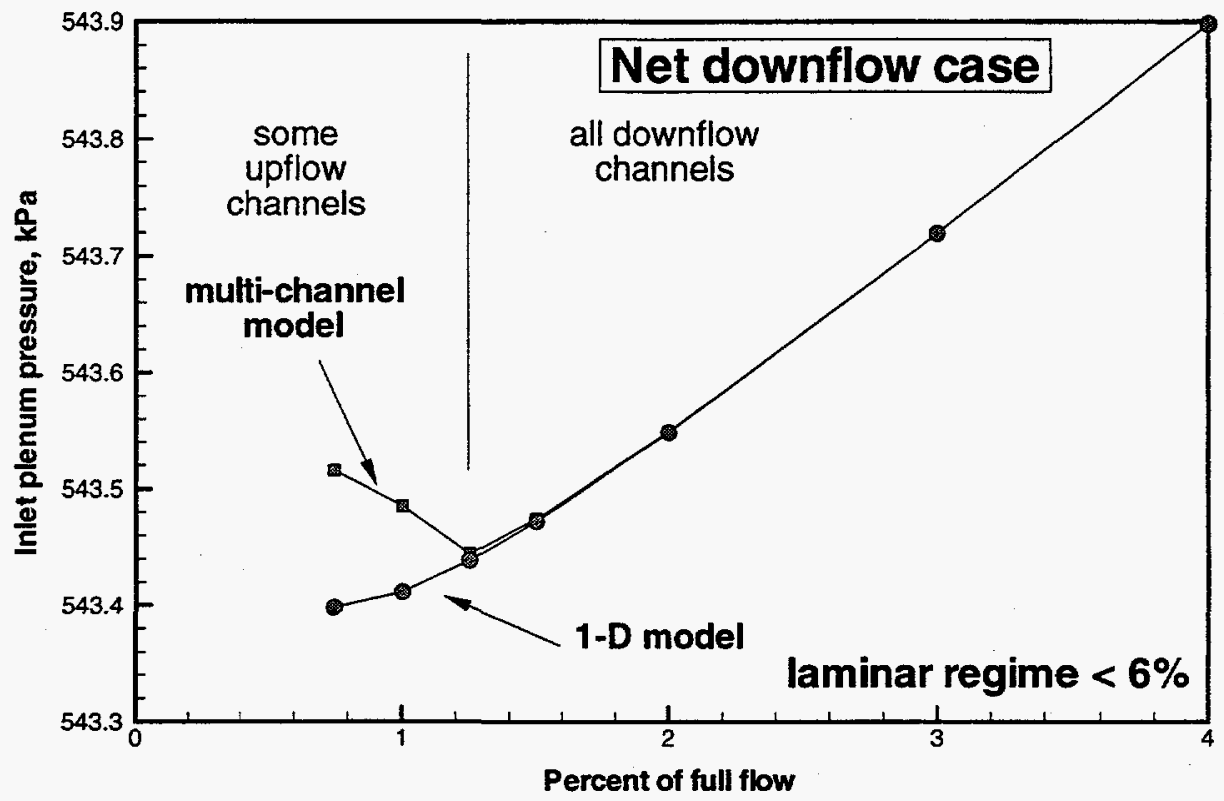

Figure 8 FLOWTRAN-TF inlet plenum pressure for front lateral Row-1 bin at 1\% power and near RHR flow conditions for the net downflow case.

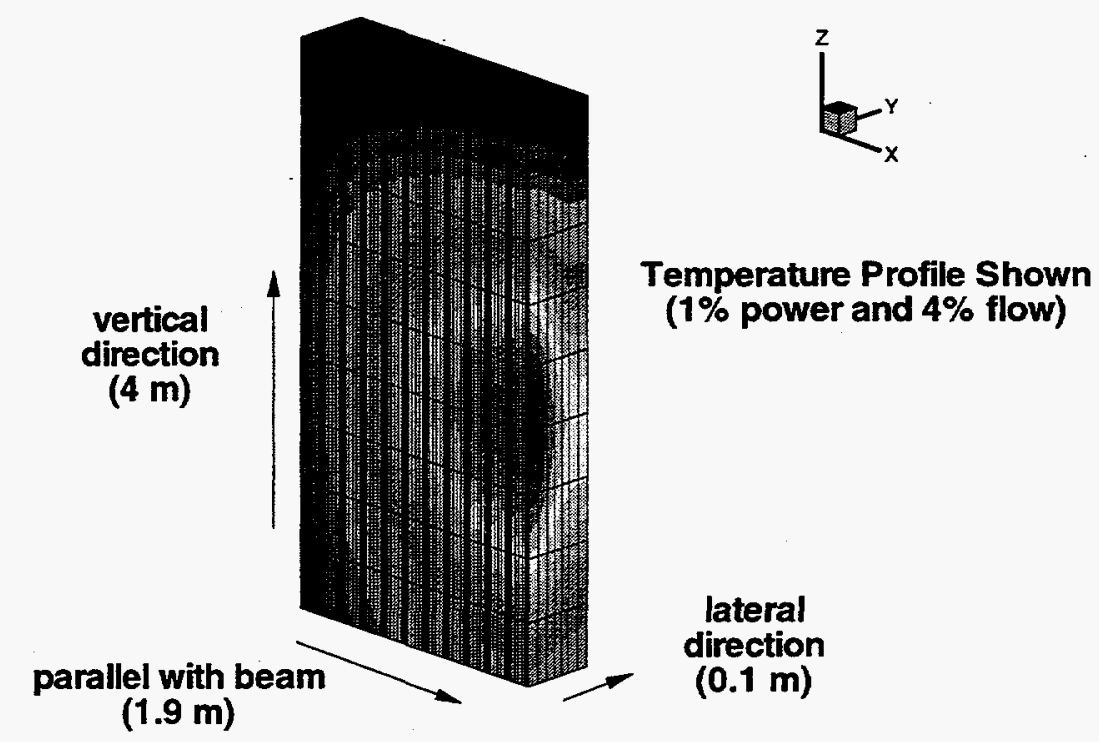

Figure 9 3-D perspective of FLOWTRAN-TF 11 channel model of front lateral Row-1 bin (temperature profile under RHR conditions for the net downflow case included). 


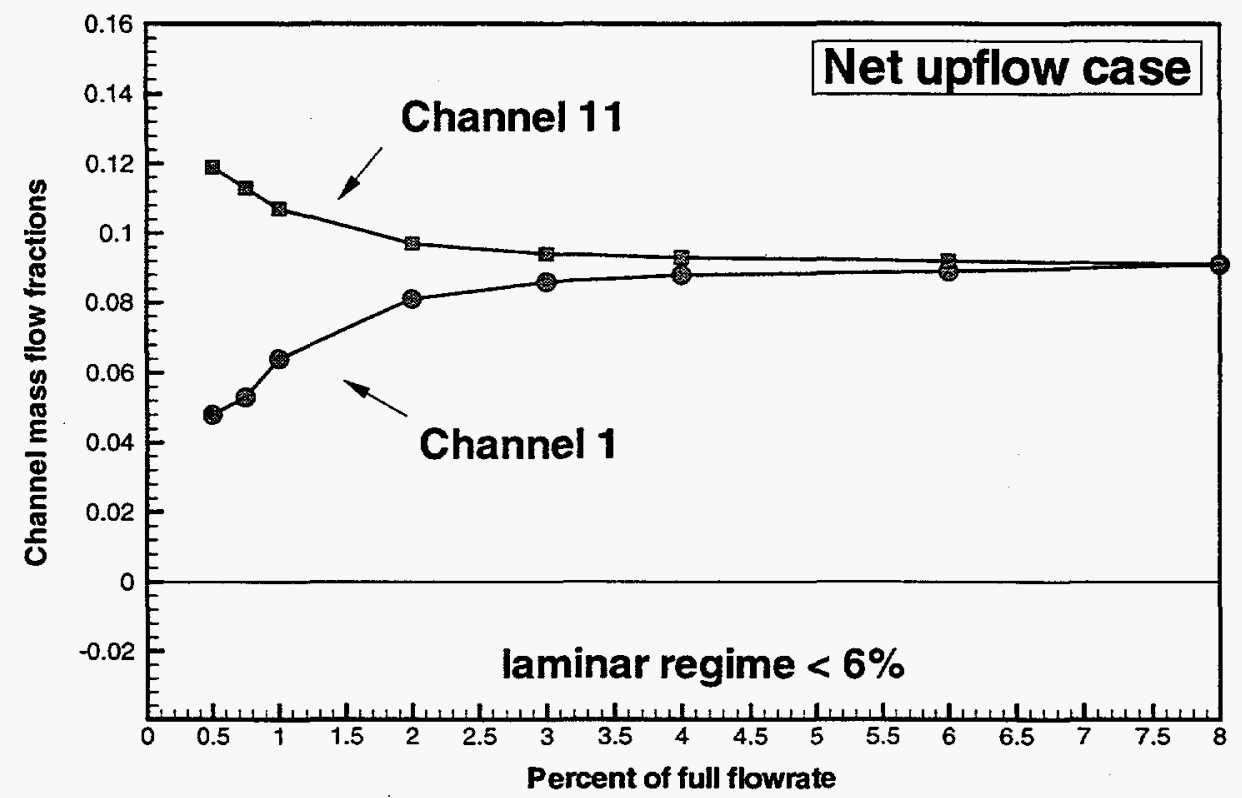

Figure 10 FLOWTRAN-TF channel 1 and 11 mass flow fractions for front lateral Row-1 bin at $1 \%$ power and near RHR flow conditions for the net upflow case.

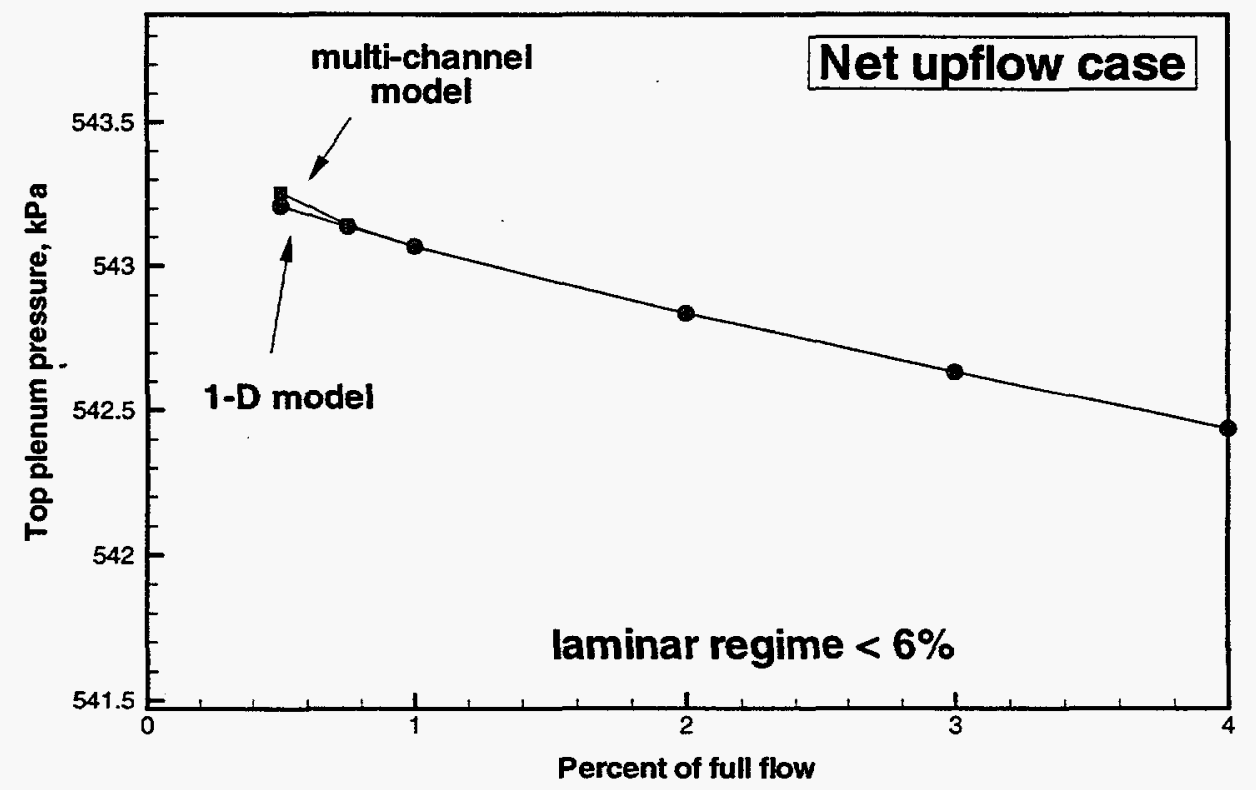

Figure 11 FLOWTRAN-TF top plenum pressure for front lateral Row-1 bin at $1 \%$ power and near RHR flow conditions for the net upflow case. 
Appendix A: Derivation of the Governing Equations for Mixed Convection Downflow through the Lumped Two-Channel APT Blanket Module

Figure 1 is a schematic of a mixed convection flow network with downflow through two parallel heated passages. This is a simple lumped model of a front lateral row 1 blanket bin. The deposited powers in the flows through the two channels differ, modeling the power tilt in the beamwise direction. The deposited powers in each of the two channels are assumed to be distributed uniformly over the lengths of the channels. The channels are assumed to be geometrically similar. The flow is assumed to be steady-state, with a Boussinesq fluid (Eq. A-1).

$$
\rho=\rho_{o}\left[1-\beta\left(T-T_{o}\right)\right]
$$

The net mass flowrate through the network is specified. Two flow regimes are considered: downflow through both channels, and upflow through the higher power channel.

\section{A.1 Downflow through Both Channels}

Figure A-1 is a schematic of a differential length of one of the channels in Fig. 1. The integral form of the linear momentum equation (eq. A-2) is applied to this control volume. For steady-state flow through a constant area duct, the left side of this equation is equal to zero. Summing the pressure, body, and wall shear forces results in an equation for the channel pressure gradient (eq. A-3). Integrating this expression over the lengths of both channels results in two expressions for the channel pressure drops. Equating the two channel pressure drops yields the momentum equation for the flow network (eq. A-4).

$$
\begin{gathered}
\frac{d}{d t} \int_{V o l} \rho \vec{V} d(V o l)+\oint_{A} \rho \vec{V}\left(\bar{V}_{r} \cdot \hat{n}\right) d A=\sum \vec{F} \\
\frac{d P}{d s}=\rho_{o} g\left[1-\beta\left(T-T_{o}\right)\right]-\frac{f \dot{m}^{2}}{2 \rho A^{2} D} \\
\rho_{o} g \beta \int_{b}^{L}\left(T_{1}-T_{o}\right) d s+\frac{f_{1} \dot{m}_{1}^{2} L}{2 \rho A_{1}^{2} D_{1}}=\rho_{o} g \beta \int_{b}^{L}\left(T_{2}-T_{o}\right) d s+\frac{f_{2} \dot{m}_{2}^{2} L}{2 \rho A_{2}^{2} D_{2}}
\end{gathered}
$$




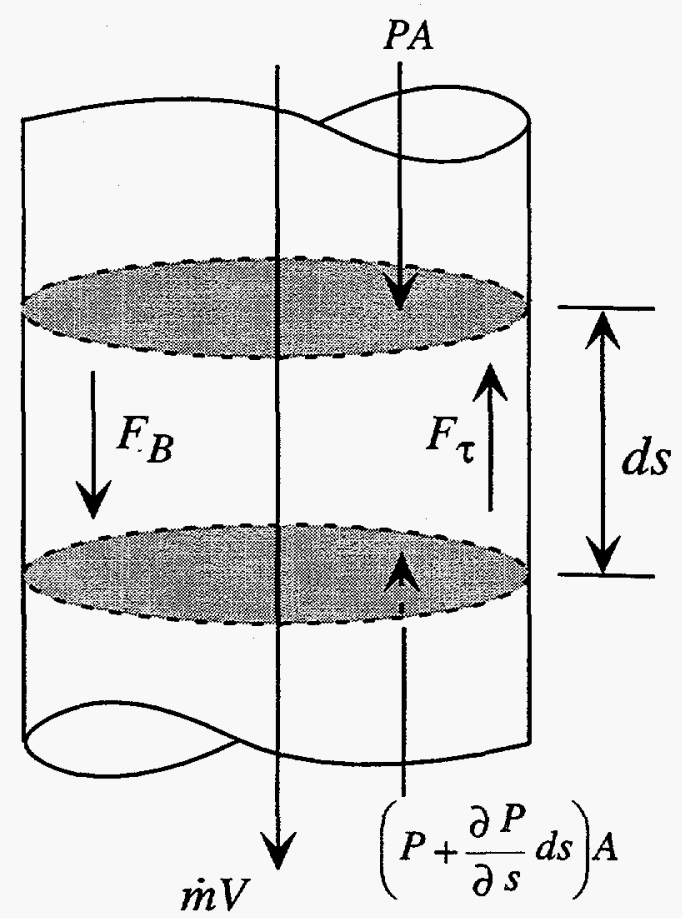

Figure A-1 A differential section of a channel with downflow, showing the applied surface and body forces.

The reference temperature (eq. A-5) is the integrated mean temperature in both channels. Substituting the expressions for the temperature distributions (eq. A-6) into eq. A-5 and integrating, results in the final expression for the reference temperature (eq. A-7).

$$
\begin{gathered}
T_{o}=\frac{1}{\left(A_{1}+A_{2}\right) L}\left[\int_{b}^{L} A_{1} T_{1} d s+\int_{0}^{L} A_{2} T_{2} d s\right] \\
T_{i}=T_{i n}+\frac{\dot{Q}_{i}}{\dot{m}_{i} C_{p}}\left(\frac{s}{L}\right) \\
T_{o}=T_{\text {in }}+\frac{1}{2 C_{p}\left(A_{1}+A_{2}\right)}\left(\frac{\dot{Q}_{1} A_{1}}{\dot{m}_{1}}+\frac{\dot{Q}_{2} A_{2}}{\dot{m}_{2}}\right)
\end{gathered}
$$

The expressions for the reference temperature and the channel temperature distributions are substituted into the momentum equation (eq. A-4), and the appropriate integrations are carried out. This yields an expression for the two channel mass flowrates (eq. A-8). The channel mass flowrates and the channel powers are normalized with the network total values for these parameters. Equation A-9 is the normalized momentum equation. The channel diameters, cross-sectional areas, and friction factors are assumed to be equal in this derivation. 


$$
\begin{gathered}
\frac{\rho_{o} g \beta \dot{Q}_{1} L}{\dot{m}_{1} C_{p}}+\frac{f_{1} \dot{m}_{1}^{2} L}{\rho A_{1}^{2} D_{1}}=\frac{\rho_{o} g \beta \dot{Q}_{2} L}{\dot{m}_{2} C_{p}}+\frac{f_{2} \dot{m}_{2}^{2} L}{\rho A_{2}^{2} D_{2}} \\
\dot{m}^{*}=\frac{\dot{m}_{1}}{\dot{m}} \& \dot{Q}^{*}=\frac{\dot{Q}_{1}}{\dot{Q}} \\
2\left(\dot{m}^{*}\right)^{3}-3\left(\dot{m}^{*}\right)^{2}+\left(1+\frac{\dot{Q} \rho^{2} A^{2} D g \beta}{f C_{p} \dot{m}^{3}}\right) \dot{m}^{*}-\frac{\dot{Q} \rho^{2} A^{2} D g \beta}{f C_{p} \dot{m}^{3}} \dot{Q}^{*}=0
\end{gathered}
$$

The non-dimensional grouping in eq. A-9 that contains the total deposited power and flowrate can be expressed in terms of the Reynolds and Grashoff numbers. The final form of the momentum equation is eqn. A-10 (eq. 1 in the main body of this document). The non-dimensional grouping with the Grashoff and Reynolds numbers is termed the Archimedes number.

$$
2\left(\dot{m}^{*}\right)^{3}-3\left(\dot{m}^{*}\right)^{2}+\left(1+\frac{G r}{f \operatorname{Re}^{2}}\right) \dot{m}^{*}-\frac{G r}{f \operatorname{Re}^{2}} \dot{Q}^{*}=0
$$

where

$$
\dot{Q}=\dot{m} C_{p} \Delta T, \quad \operatorname{Re}=\frac{\rho V D}{\mu}, \& \quad G r=\frac{g \beta D^{3} \Delta T}{v^{2}}
$$

\section{A.2 Upflow through the High Power Channel}

There is the possibility for upflow through the higher power channel. The momentum equation for this flow situation was derived in the same manner as the case with downflow through both channels. Channel one is assumed to be the higher power channel, and upflow is assumed through this channel. Figure A-2 is a schematic of a differential length of the upflow channel, showing the applied forces on the control volume. With upflow, the direction of the wall shear force is down. Application of the linear momentum equation to this control volume and integrating, results in an expression for the pressure drop along the upflow channel. Equating this pressure drop with the pressure drop in the downflow channel, results in a momentum equation analogous to eq. A-4 for the case with downflow through both channels. Equations A-11 and $A-12$ are the temperature distributions in channels one and two respectively. The top and bottom plenums are assumed to be well mixed and isothermal. Equation A-13 is the expression for the reference temperature. Substituting these temperature expressions into the momentum equation and integrating, results in an expression for the two channel mass flowrates (eq A-14). This equation is normalized in the same fashion as for the case with downflow through both channels. Equation A-15 is the expression for the normalized upflow as a function of the channel power split and system flowrate. This is eq. 2 in the main body of this document. The flow directions were assumed in this derivation, therefore an upward mass flowrate ratio in the high power leg is positive. 
WESTINGHOUSE SAVANNAH RIVER COMPANY

APT BLANKET SAFETY ANALYSIS:

(DOWNFLOW THROUGH A FRONT LATERAL ROW-1 MODULE)
Report:

Section:

Date:

Page:
WSRC-TR-98-0163

Appendix A

07/29/98

4 of 4

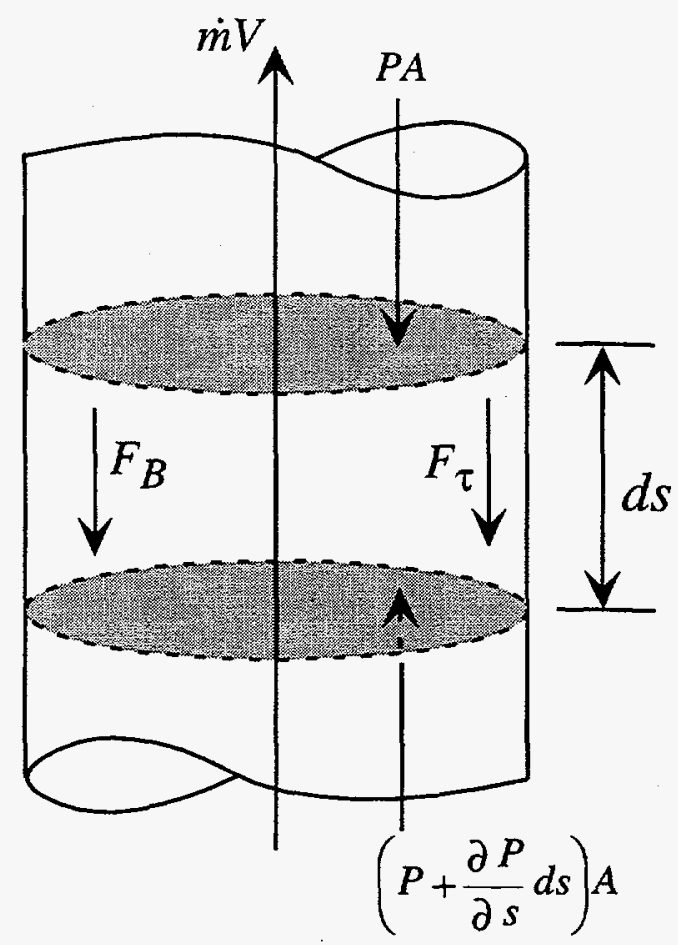

Figure A-2 A differential section of the higher power channel with upflow, showing the applied surface and body forces.

$$
\begin{gathered}
T_{1}=T_{\text {out }}+\frac{\dot{Q}_{1}}{\dot{m}_{1} C_{p}}\left(1-\frac{s}{L}\right) \\
T_{2}=T_{\text {out }}-\frac{\dot{Q}_{2}}{\dot{m}_{2} C_{p}}\left(1-\frac{s}{L}\right) \\
T_{o}=T_{\text {out }}+\frac{1}{4 C_{p}}\left(\frac{\dot{Q}_{1}}{\dot{m}_{1}}-\frac{\dot{Q}_{2}}{\dot{m}_{2}}\right) \\
\frac{f C_{p}}{\rho^{2} A^{2} g \beta D}\left(\dot{m}_{1}^{2}+\dot{m}_{2}^{2}\right)-\frac{\dot{Q}_{1}}{\dot{m}_{1}}-\frac{\dot{Q}_{2}}{\dot{m}_{2}}=0 \\
2\left(\dot{m}^{*}\right)^{4}+4\left(\dot{m}^{*}\right)^{3}+3\left(\dot{m}^{*}\right)^{2}+\left(1-\frac{G r}{f \operatorname{Re}^{2}}\right) \dot{m}^{*}-\frac{G r}{f \operatorname{Re}^{2}} \dot{Q}^{*}=0
\end{gathered}
$$




\section{Appendix B: FLOWTRAN-TF Input File for Front Lateral Row-1 Bin (downflow and upflow under near RHR conditions)}

Below is a listing of the FLOWTRAN-TF input deck for the 11 channel model of a front lateral Row-1 bin. The finite element input of the solid geometric parameters is based on the most recently available information concerning a front lateral Row-1 bin taken from a slide presentation presented by Rick Kapernick at a LANL information meeting held March 31, 1998 [Ref. 2].

Input file chn11.in:

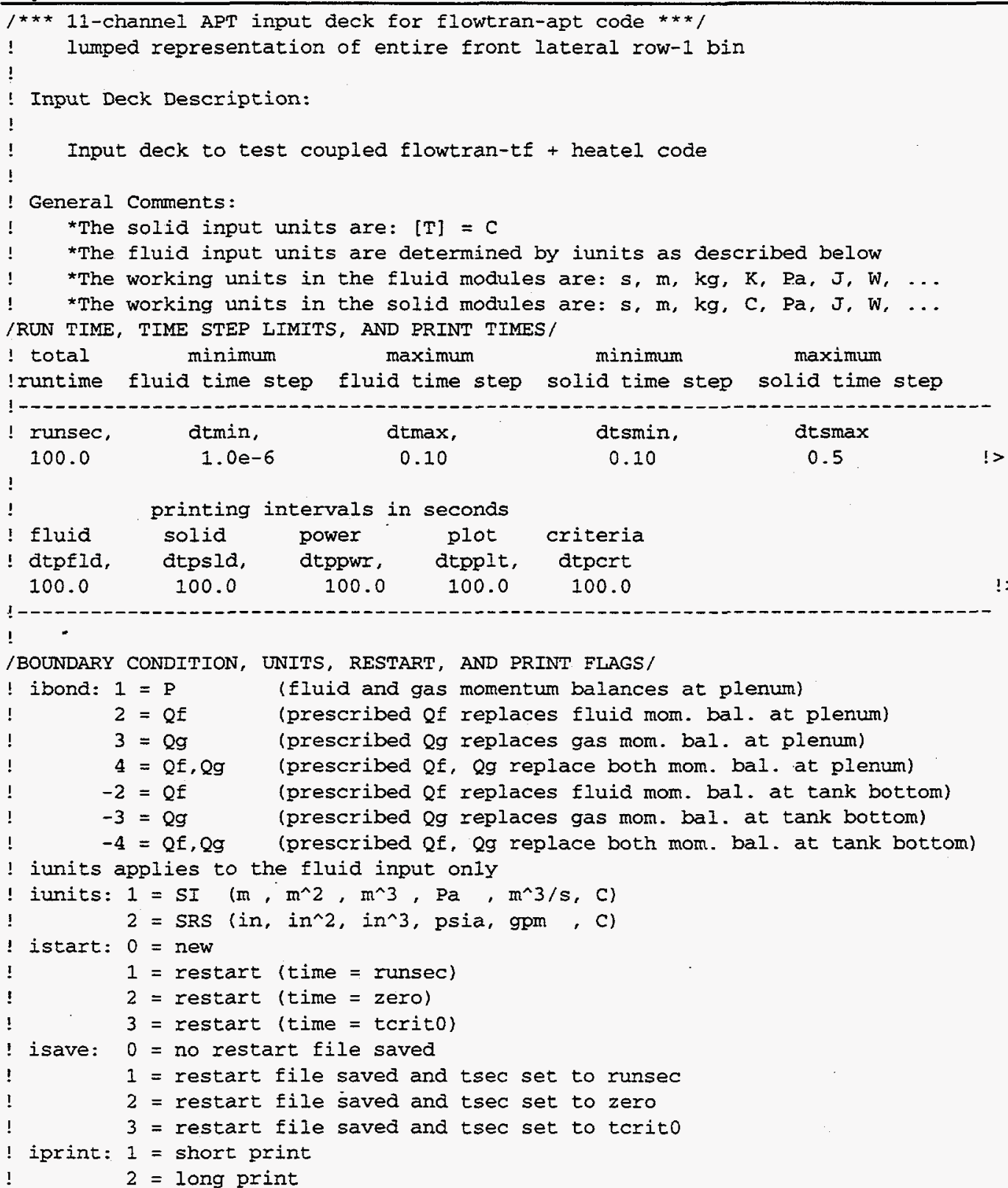




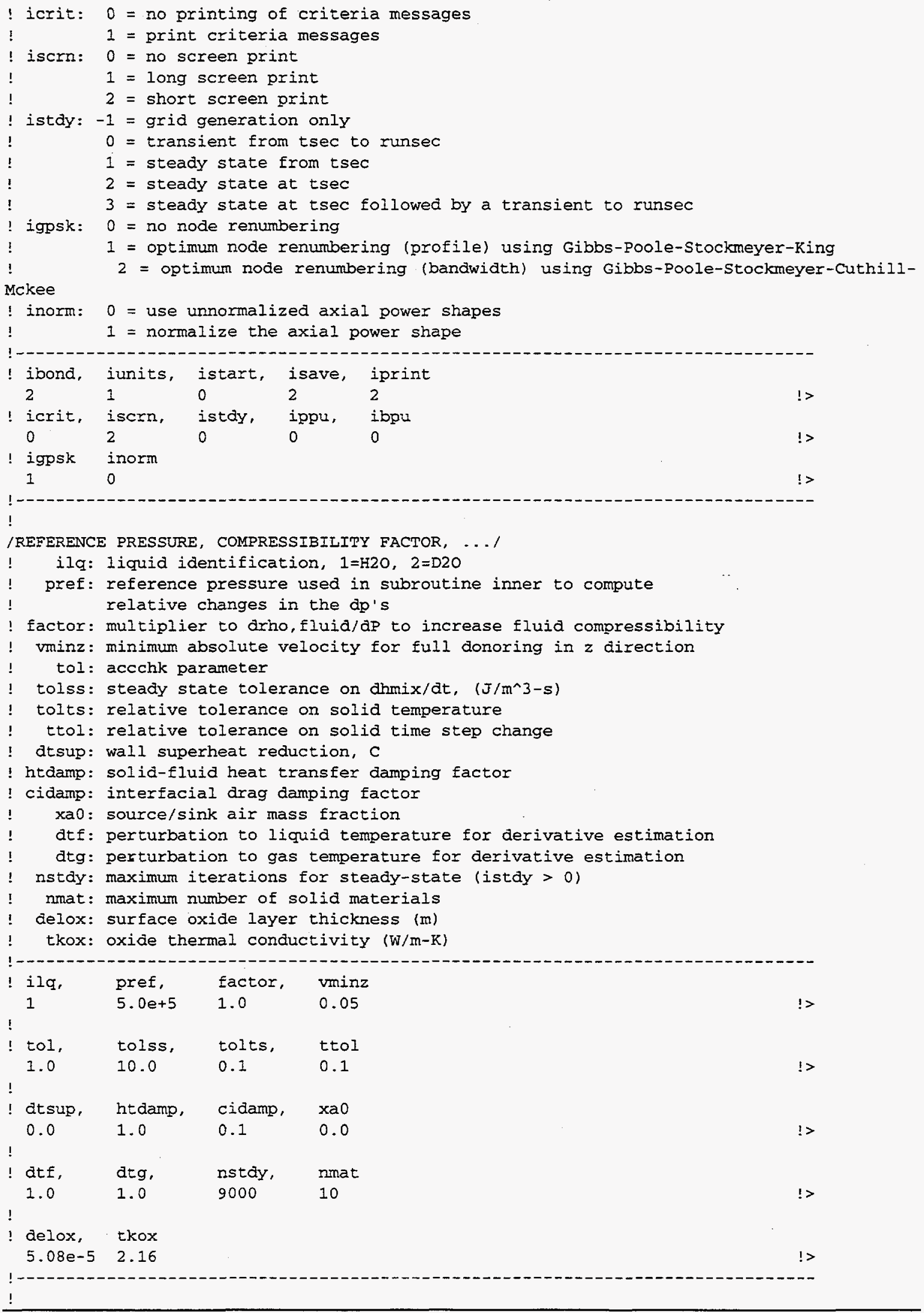


/BOILING CURVE AND INTERPHASE TRANSPORT OPTIONS/

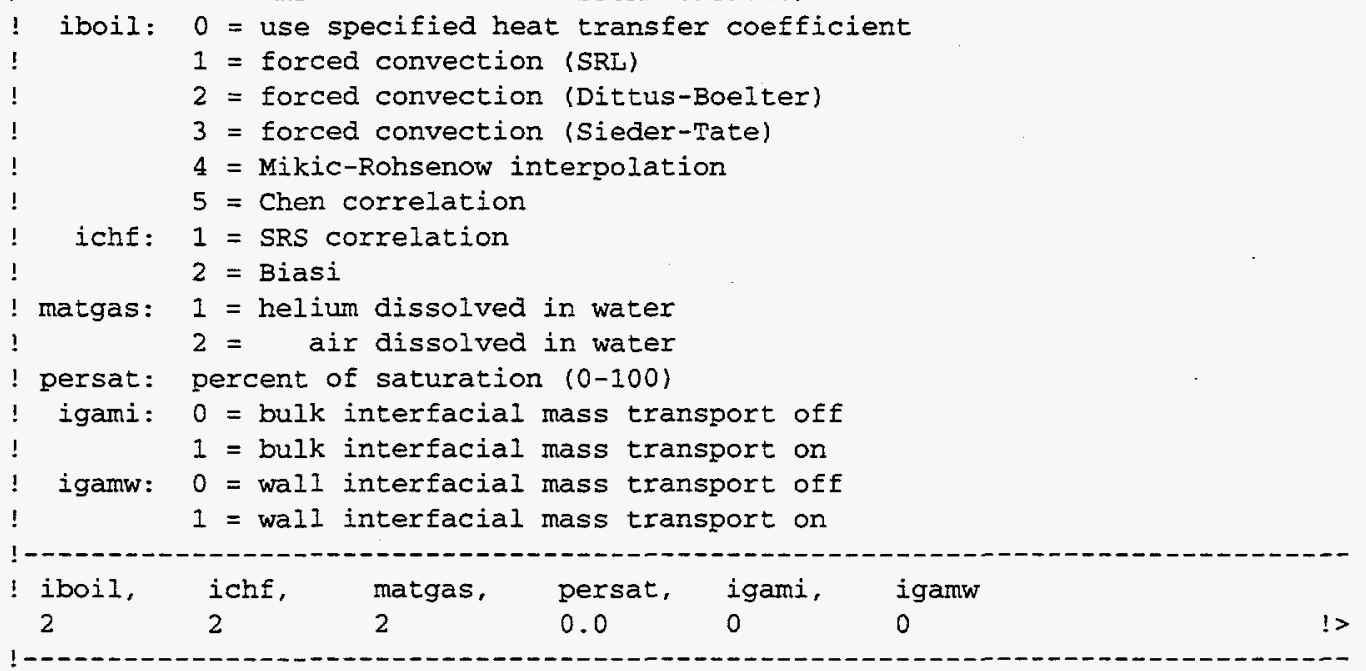

$$
\text { ! }
$$


/NUMBER OF SPIINE PROFILES AND DATA POINTS/

! ndata: number of data groups

! itime: number of time snapshots for axial power profiles

! ndata, itime

$$
42
$$

! npdat: number of data points per data set

! nset: number of data sets in data group

! npdat nset

$\begin{array}{rll}3 & 1 & 1> \\ 4 & 1 & 1> \\ 29 & 1 & 1> \\ 3 & 1 & 1> \\ & & \end{array}$


! inbp - number of boundary points

! iflag - output flag ( 1 = echo input, $0=$ no input echo)

$/$ inrg inbp iflag /

$$
58 \quad 260 \quad 1
$$

!

! node $(x, y)$ coordinates within grid

$/$ jnod xp(jnod) yp(jnod) i=1, inbp (cm) /

$10.00000 \quad 0.00000$

$\begin{array}{lll}2 & 0.01270 & 0.00000\end{array}$

$3 \quad 0.02540 \quad 0.00000$

$\begin{array}{lll}4 & 0.08636 & 0.00000\end{array}$

$\begin{array}{lll}5 & 0.14732 & 0.00000\end{array}$

$\begin{array}{lll}6 & 0.17272 & 0.00000\end{array}$

$\begin{array}{lll}7 & 0.19812 & 0.00000\end{array}$

$\begin{array}{lll}8 & 0.25908 & 0.00000\end{array}$

$9 \quad 0.32004 \quad 0.00000$

$\begin{array}{lll}10 & 0.34544 & 0.00000\end{array}$

$11 \quad 0.37084 \quad 0.00000$

$120.43180 \quad 0.00000$

$\begin{array}{lll}13 & 0.49276 & 0.00000\end{array}$

$14 \quad 0.51816 \quad 0.00000$

$\begin{array}{lll}15 & 0.54356 & 0.00000\end{array}$

$\begin{array}{lll}16 & 0.60452 & 0.00000\end{array}$

$\begin{array}{lll}17 & 0.66548 & 0.00000\end{array}$

$\begin{array}{lll}18 & 0.69088 & 0.00000\end{array}$

$\begin{array}{lll}19 & 0.71628 & 0.00000\end{array}$

$\begin{array}{lll}20 & 0.77724 & 0.00000\end{array}$

$21 \quad 0.83820 \quad 0.00000$

$22 \quad 0.86360 \quad 0.00000$

$\begin{array}{lll}23 & 0.88900 & 0.00000\end{array}$

$24 \quad 0.94996 \quad 0.00000$

$\begin{array}{lll}25 & 1.01092 & 0.00000\end{array}$

$\begin{array}{lll}26 & 1.03632 & 0.00000\end{array}$

$\begin{array}{lll}27 & 1.06172 & 0.00000\end{array}$

$\begin{array}{lll}28 & 1.12268 & 0.00000\end{array}$

$\begin{array}{lll}29 & 1.18364 & 0.00000\end{array}$

$\begin{array}{lll}30 & 1.20904 & 0.00000\end{array}$

$\begin{array}{lll}31 & 1.23444 & 0.00000\end{array}$

$32 \quad 1.29540 \quad 0.00000$

$\begin{array}{lll}33 & 1.35636 & 0.00000\end{array}$

$34 \quad 1.38176 \quad 0.00000$

$\begin{array}{lll}35 & 1.40716 & 0.00000\end{array}$

$\begin{array}{lll}36 & 1.46812 & 0.00000\end{array}$

$37 \quad 1.52908 \quad 0.00000$

$\begin{array}{lll}38 & 1.55448 & 0.00000\end{array}$

$\begin{array}{lll}39 & 1.57988 & 0.00000\end{array}$

$40 \quad 1.64084 \quad 0.00000$

$\begin{array}{lll}41 & 1.70180 & 0.00000\end{array}$

$42 \quad 1.72720 \quad 0.00000$

$43 \quad 1.75260 \quad 0.00000$

$\begin{array}{lll}44 & 1.81356 & 0.00000\end{array}$

$45 \quad 1.87452 \quad 0.00000$

$\begin{array}{lll}46 & 1.88722 & 0.00000\end{array}$

$47 \quad 1.89992 \quad 0.00000$

$\begin{array}{lll}48 & 0.00000 & 0.01557\end{array}$

$\begin{array}{lll}49 & 0.02540 & 0.01557\end{array}$

$\begin{array}{lll}50 & 0.14732 & 0.01557\end{array}$

$\begin{array}{lll}51 & 0.19812 & 0.01557\end{array}$

$\begin{array}{lll}52 & 0.32004 & 0.01557\end{array}$

$\begin{array}{lll}53 & 0.37084 & 0.01557\end{array}$ 
Report:

Section:

Date:

Page:
WSRC-TR-98-0163

Appendix B

$07 / 29 / 98$

6 of 20

(DOWNFLOW THROUGH A FRONT LATERAL ROW-1 MODULE)
0.49276
0.01557
0.54356
0.01557
0.66548
0.01557
0.71628
0.01557
0.83820
0.01557
0.88900
0.01557
1.01092
0.01557
1.06172
0.01557
1.18364
0.01557
1.23444
0.01557
1.35635
0.01557
1.40716
0.01557
1.52908
0.01557
1.57988
0.01557
1.70180
0.01557
1.75260
0.01557
1.87452
0.01557
1.89992
0.01557
0.00000
0.03113
0.01270
0.03113
0.02540
0.03113
0.08636
0.03113
0.14732
0.03113
0.17272
0.03113
0.19812
0.03113
0.25908
0.03113
0.32004
0.03113
0.34544
0.03113
0.37084
0.03113
0.43180
0.03113
0.49276
0.03113
0.51816
0.03113
0.54356
0.03113
0.60452
0.03113
0.66548
0.03113
0.69088
0.03113
0.71628
0.03113
0.77724
0.03113
0.83820
0.03113
0.86360
0.03113
0.88900
0.03113
0.94996
0.03113
1.01092
0.03113
1.03632
0.03113
1.06172
0.03113
1.12268
0.03113
1.18364
0.03113
1.20904
0.03113
1.23444
0.03113
1.29540
0.03113
1.35636
0.03113
1.38176
0.03113
1.40716
0.03113
1.46812
0.03113
1.52908
0.03113
1.55448
0.03113
1.57988
0.03113
1.64084
0.03113
1.70180
0.03113
1.72720
0.03113
1.75260
0.03113
1.81356
0.03113

115 


\begin{tabular}{|c|c|c|}
\hline 116 & 1.87452 & 0.03113 \\
\hline 117 & 1.88722 & 0.03113 \\
\hline 118 & 1.89992 & 0.03113 \\
\hline 119 & 0.00000 & 0.04923 \\
\hline 120 & 0.02540 & 0.04923 \\
\hline 21 & 0.14732 & 0.04923 \\
\hline 22 & 0.19812 & 0.04923 \\
\hline 123 & 0.32004 & 0.04923 \\
\hline 124 & 0.37084 & 0.04923 \\
\hline 125 & 0.49276 & 0.04923 \\
\hline 126 & 0.54356 & 0.04923 \\
\hline 127 & 0.66548 & 0.04923 \\
\hline 128 & 0.71628 & 0.04923 \\
\hline 129 & 0.83820 & 0.04923 \\
\hline 130 & 0.88900 & 0.04923 \\
\hline 131 & 1.01092 & 0.04923 \\
\hline 132 & 1.06172 & 0.04923 \\
\hline 133 & 1.18364 & 0.04923 \\
\hline 134 & 1.23444 & 0.04923 \\
\hline 135 & 1.35636 & 0.04923 \\
\hline 136 & 1.40716 & 0.04923 \\
\hline 137 & 1.52908 & 0.04923 \\
\hline 138 & 1.57988 & 0.04923 \\
\hline 139 & 1.70180 & 0.04923 \\
\hline 140 & 1.75260 & 0.04923 \\
\hline 141 & 1.87452 & 0.04923 \\
\hline 142 & 1.89992 & 0.04923 \\
\hline 143 & 0.00000 & 0.06732 \\
\hline 144 & 0.01270 & 0.06732 \\
\hline 145 & 0.02540 & 0.06732 \\
\hline 146 & 0.08636 & 0.06732 \\
\hline 147 & 0.14732 & 0.06732 \\
\hline 148 & 0.17272 & 0.06732 \\
\hline 149 & 0.19812 & 0.06732 \\
\hline 150 & 0.25908 & 0.06732 \\
\hline 151 & 0.32004 & 0.06732 \\
\hline 152 & 0.34544 & 0.06732 \\
\hline 153 & 0.37084 & 0.06732 \\
\hline 154 & 0.43180 & 0.06732 \\
\hline 155 & 0.49276 & 0.06732 \\
\hline 156 & 0.51816 & 0.06732 \\
\hline 157 & 0.54356 & 0.06732 \\
\hline 158 & 0.60452 & 0.06732 \\
\hline 159 & 0.66548 & 0.06732 \\
\hline 160 & 0.69088 & 0.06732 \\
\hline 161 & 0.71628 & 0.06732 \\
\hline 162 & 0.77724 & 0.06732 \\
\hline 163 & 0.83820 & 0.06732 \\
\hline 164 & 0.86360 & 0.06732 \\
\hline 165 & 0.88900 & 0.06732 \\
\hline 166 & 0.94996 & 0.06732 \\
\hline 167 & 1.01092 & 0.06732 \\
\hline 168 & 1.03632 & 0.06732 \\
\hline 159 & 1.06172 & 0.06732 \\
\hline 170 & 1.12268 & 0.06732 \\
\hline 171 & 1.18364 & 0.06732 \\
\hline 172 & 1.20904 & 0.06732 \\
\hline 173 & 1.23444 & 0.06732 \\
\hline 174 & 1.29540 & 0.06732 \\
\hline 175 & 1.35636 & 0.06732 \\
\hline 176 & 1.38176 & 0.06732 \\
\hline 177 & 1.40716 & 0.06732 \\
\hline
\end{tabular}




\begin{tabular}{|c|c|c|}
\hline 178 & 1.46812 & 0.06732 \\
\hline 179 & 1.52908 & 0.06732 \\
\hline 180 & I. 55448 & 0.06732 \\
\hline 181 & 1.57988 & 0.06732 \\
\hline 182 & 1.64084 & 0.06732 \\
\hline 183 & 1.70180 & 0.06732 \\
\hline 184 & 1.72720 & 0.06732 \\
\hline 185 & 1.75260 & 0.06732 \\
\hline 186 & 1.81356 & 0.06732 \\
\hline 187 & 1.87452 & 0.06732 \\
\hline 188 & 1.88722 & 0.06732 \\
\hline 189 & 1.89992 & 0.06732 \\
\hline 190 & 0.00000 & 0.08288 \\
\hline 191 & 0.02540 & 0.08288 \\
\hline 192 & 0.14732 & 0.08288 \\
\hline 193 & 0.19812 & 0.08288 \\
\hline 194 & 0.32004 & 0.08288 \\
\hline 195 & 0.37084 & 0.08288 \\
\hline 196 & 0.49276 & 0.08288 \\
\hline 197 & 0.54356 & 0.08288 \\
\hline 198 & 0.66548 & 0.08288 \\
\hline 199 & 0.71628 & 0.08288 \\
\hline 200 & 0.83820 & 0.08288 \\
\hline 201 & 0.88900 & 0.08288 \\
\hline 202 & 1.01092 & 0.08288 \\
\hline 203 & 1.06172 & 0.08288 \\
\hline 204 & 1.18364 & 0.08288 \\
\hline 205 & 1.23444 & 0.08288 \\
\hline 206 & 1.35636 & 0.08288 \\
\hline 207 & 1. 40716 & 0.08288 \\
\hline 208 & 1.52908 & 0.08288 \\
\hline 209 & 1.57988 & 0.08288 \\
\hline 210 & 1.70180 & 0.08288 \\
\hline 211 & 1.75260 & 0.08288 \\
\hline 212 & 1.87452 & 0.08288 \\
\hline 213 & 1.89992 & 0.08288 \\
\hline 214 & 0.00000 & 0.09845 \\
\hline 215 & 0.01270 & 0.09845 \\
\hline 216 & 0.02540 & 0.09845 \\
\hline 217 & 0.08636 & 0.09845 \\
\hline 218 & 0.14732 & 0.09845 \\
\hline 219 & 0.17272 & 0.09845 \\
\hline 220 & 0.19812 & 0.09845 \\
\hline 221 & 0.25908 & 0.09845 \\
\hline 222 & 0.32004 & 0.09845 \\
\hline 223 & 0.34544 & 0.09845 \\
\hline 224 & 0.37084 & 0.09845 \\
\hline 225 & 0.43180 & 0.09845 \\
\hline 226 & 0.49276 & 0.09845 \\
\hline 227 & 0.51816 & 0.09845 \\
\hline 228 & 0.54356 & 0.09845 \\
\hline 229 & 0.60452 & 0.09845 \\
\hline 230 & 0.66548 & 0.09845 \\
\hline 231 & 0.69088 & 0.09845 \\
\hline 232 & 0.71628 & 0.09845 \\
\hline 233 & 0.77724 & 0.09845 \\
\hline 234 & 0.83820 & 0.09845 \\
\hline 235 & 0.86360 & 0.09845 \\
\hline 236 & 0.88900 & 0.09845 \\
\hline 237 & 0.94996 & 0.09845 \\
\hline 238 & 1.01092 & 0.09845 \\
\hline 239 & 1.03632 & 0.09845 \\
\hline
\end{tabular}




$\begin{array}{lll}240 & 1.06172 & 0.09845 \\ 241 & 1.12268 & 0.09845 \\ 242 & 1.18364 & 0.09845 \\ 243 & 1.20904 & 0.09845 \\ 244 & 1.23444 & 0.09845 \\ 245 & 1.29540 & 0.09845 \\ 246 & 1.35636 & 0.09845 \\ 247 & 1.38176 & 0.09845 \\ 248 & 1.40716 & 0.09845 \\ 249 & 1.46812 & 0.09845 \\ 250 & 1.52908 & 0.09845 \\ 251 & 1.55448 & 0.09845 \\ 252 & 1.57988 & 0.09845 \\ 253 & 1.64084 & 0.09845 \\ 254 & 1.70180 & 0.09845 \\ 255 & 1.72720 & 0.09845 \\ 256 & 1.75260 & 0.09845 \\ 257 & 1.81356 & 0.09845 \\ 258 & 1.87452 & 0.09845 \\ 259 & 1.88722 & 0.09845 \\ 260 & 1.89992 & 0.09845\end{array}$


WESTINGHOUSE SAVANNAH RIVER COMPANY

APT BLANKET SAFETY ANALYSIS:

(DOWNFLOW THROUGH A FRONT LATERAL ROW-1 MODULE)
Report:

Section:

Date:

Page:
WSRC-TR-98-0163

Appendix B

$07 / 29 / 98$ 10 of 20

$\begin{array}{rrrrr}38 & 0 & 37 & -2 & 36 \\ 39 & 0 & 42 & 26 & 40 \\ 40 & 0 & 39 & -2 & 37 \\ 41 & 0 & 44 & 27 & 42 \\ 42 & 0 & 41 & -2 & 39 \\ 43 & 0 & 46 & 28 & 44 \\ 44 & 0 & 43 & -2 & 41 \\ 45 & 0 & 48 & 29 & 46 \\ 46 & 0 & 45 & -2 & 43 \\ 47 & 0 & 50 & 30 & 48 \\ 48 & 0 & 47 & -2 & 45 \\ 49 & 0 & 52 & 31 & 50 \\ 50 & 0 & 49 & -2 & 47 \\ 51 & 0 & 54 & 32 & 52 \\ 52 & 0 & 51 & -2 & 49 \\ 53 & 0 & 56 & 33 & 54 \\ 54 & 0 & 53 & -2 & 51 \\ 55 & 0 & 58 & 34 & 56 \\ 56 & 0 & 55 & -2 & 53 \\ 57 & 0 & 0 & 35 & 58 \\ 58 & 0 & 57 & -2 & 55\end{array}$

$!$

regional data

material $g=$ dummy test metal

/ regional data /

$\begin{array}{llllllllllll}1 & 10 & 3 & 3 & 1 & 2 & 3 & 49 & 74 & 73 & 72 & 48\end{array}$

$\begin{array}{llllllllllll}2 & 10 & 3 & 5 & 3 & 4 & 5 & 50 & 76 & 75 & 74 & 49\end{array}$

$\begin{array}{rrrrrrrrrrrr}2 & 1 & 1 & & & & & & & & \\ 3 & 10 & 3 & 5 & 5 & 6 & 7 & 51 & 78 & 77 & 76 & 50\end{array}$

$\begin{array}{llllllllllll}4 & 10 & 3 & 5 & 7 & 8 & 9 & 52 & 80 & 79 & 78 & 51\end{array}$

$\begin{array}{rrrrrrrrrrrr}4 & 1 & 2 & & & & & & & & \\ 5 & 10 & 3 & 5 & 9 & 10 & 11 & 53 & 82 & 81 & 80 & 52\end{array}$

$\begin{array}{rrrrrrrrrrrr}5 & 10 & 3 & 5 & 9 & 10 & 11 & 53 & 82 & 81 & 80 & 52 \\ 6 & 10 & 3 & 5 & 11 & 12 & 13 & 54 & 84 & 83 & 82 & 53\end{array}$

$6 \quad 1 \quad 3$

$\begin{array}{llllllllllll}7 & 10 & 3 & 5 & 13 & 14 & 15 & 55 & 86 & 85 & 84 & 54\end{array}$

$\begin{array}{llllllllllll}8 & 10 & 3 & 5 & 15 & 16 & 17 & 56 & 88 & 87 & 86 & 55\end{array}$

$\begin{array}{rrrrrrrrrrrr}8 & 1 & 4 & & & & & & & & \\ 9 & 10 & 3 & 5 & 17 & 18 & 19 & 57 & 90 & 89 & 88 & 56\end{array}$

$\begin{array}{llllllllllll}10 & 10 & 3 & 5 & 19 & 20 & 21 & 58 & 92 & 91 & 90 & 57\end{array}$

$101-5$

$11 \quad 10 \quad 3$

$1210 \quad 3$

12116

$1310 \quad 3$

$1410 \quad 3$

141517

$15 \quad 10 \quad 3$

$\begin{array}{lllllllll}5 & 21 & 22 & 23 & 59 & 94 & 93 & 92 & 58\end{array}$

$\begin{array}{lllllllll}5 & 23 & 24 & 25 & 60 & 96 & 95 & 94 & 59\end{array}$

$\begin{array}{rrrrrrrrr}5 & 25 & 26 & 27 & 61 & 98 & 97 & 96 & 60\end{array}$

$\begin{array}{lllllllll}5 & 27 & 28 & 29 & 62 & 100 & 99 & 98 & 61\end{array}$

$\begin{array}{lllllllll}5 & 29 & 30 & 31 & 63 & 102 & 101 & 100 & 62\end{array}$

$\begin{array}{lllllllll}5 & 31 & 32 & 33 & 64 & 104 & 103 & 102 & 63\end{array}$

$\begin{array}{lllllllll}5 & 33 & 34 & 35 & 65 & 106 & 105 & 104 & 64\end{array}$

$\begin{array}{lllllllll}5 & 35 & 36 & 37 & 66 & 108 & 107 & 106 & 65\end{array}$

$\begin{array}{lllllllll}5 & 37 & 38 & 39 & 67 & 110 & 109 & 108 & 66\end{array}$

$\begin{array}{lllllllll}5 & 39 & 40 & 41 & 68 & 112 & 111 & 110 & 67\end{array}$

$\begin{array}{lllllllll}5 & 41 & 42 & 43 & 69 & 114 & 113 & 112 & 68\end{array}$

$\begin{array}{lllllllll}5 & 43 & 44 & 45 & 70 & 116 & 115 & 114 & 69\end{array}$

$\begin{array}{lllllllll}3 & 45 & 46 & 47 & 71 & 118 & 117 & 116 & 70\end{array}$

$23 \quad 10 \quad 3$

2410

$\begin{array}{lllllllll}3 & 72 & 73 & 74 & 120 & 145 & 144 & 143 & 119\end{array}$ 
APT BLANKET SAFETY ANALYSIS:

$\begin{array}{rrrrrrrrrrrr}56 & 3 & 10 & & & & & & & \\ 57 & 10 & 3 & 3 & 187 & 188 & 189 & 213 & 260 & 259 & 258 & 212 \\ 58 & 10 & 3 & 5 & 185 & 186 & 187 & 212 & 258 & 257 & 256 & 211 \\ 58 & 3 & 11 & & & & & & & & & \end{array}$

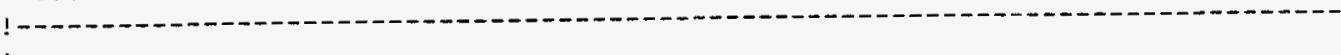

/TOP SECTION GEOMETRY/

Axial mesh spacing

iuform: 1 = uniform axial mesh spacing

2 = individually specified values

dztot: total axial length if iuform=1; not used if iuform $=2$

(must be specified however)

!dzt $(j z)$ : axial cell lengths if iuform=2

$!$ iuform
1 dztot
$\quad 0: 1$

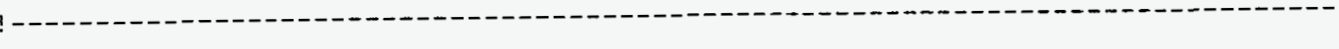

iuform: 1 = uniform mass cell volumes and junction variables

iuform: $\begin{aligned} & 1 \text { = uniform mass cell volumes and } \\ & 2 \text { = individually specified values }\end{aligned}$

1.

1

$\operatorname{volt}(j z):(c e 11)$ volume

act $(j z):$ (face) junction area

azt $(j z):-(c e l l)$ mid-cell or volume-averaged area

cost $(j z):$ (face) cos (theta)

cht $(j z):$ (face) hydraulic diameter

absrt $(j z):$ (face) absolute roughness

fmltt $(j z):$ (face) friction multiplier $(0$ or 1 normaliy)

fret $(j z):$ (face) $64 / f R e$

! formt $(j z):$ (face) form loss $k$ factor

defft(jz): (face) characteristic dimension for slug regime

! flant $(j z):$ (face) m constant in flooding correlation

! flact $(j z):$ (face) c constant in flooding correlation

cobt (jz): (face) co for bubbly regime

cost $(j z):$ (face) co for slug regime

ckbt (jz): (face) kb for bubbly regime

ckst $(j z)$ : (face) ks for slug regime

!

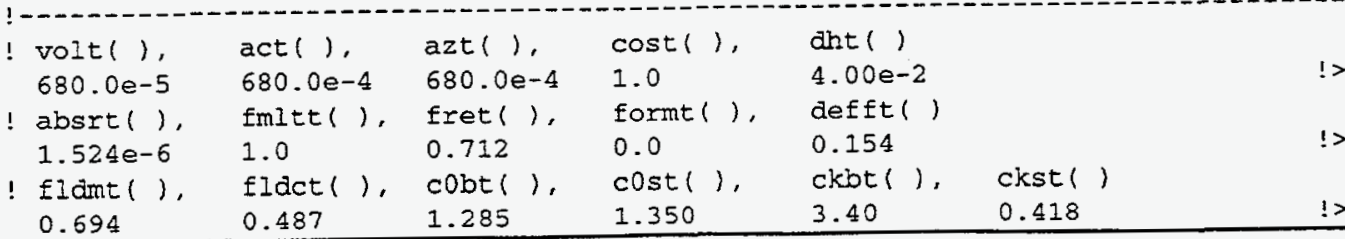


1

/MIDDLE SECTION GEOMETRY/

! iuform: 1 = uniform axial mesh spacing

2 = individually specified values

dztot: total axial length if iuform $=1$

$\mathrm{dz}$ : axial cell lengths if iuform $=2$

! iuform

1

! aztot

4.0

Page:

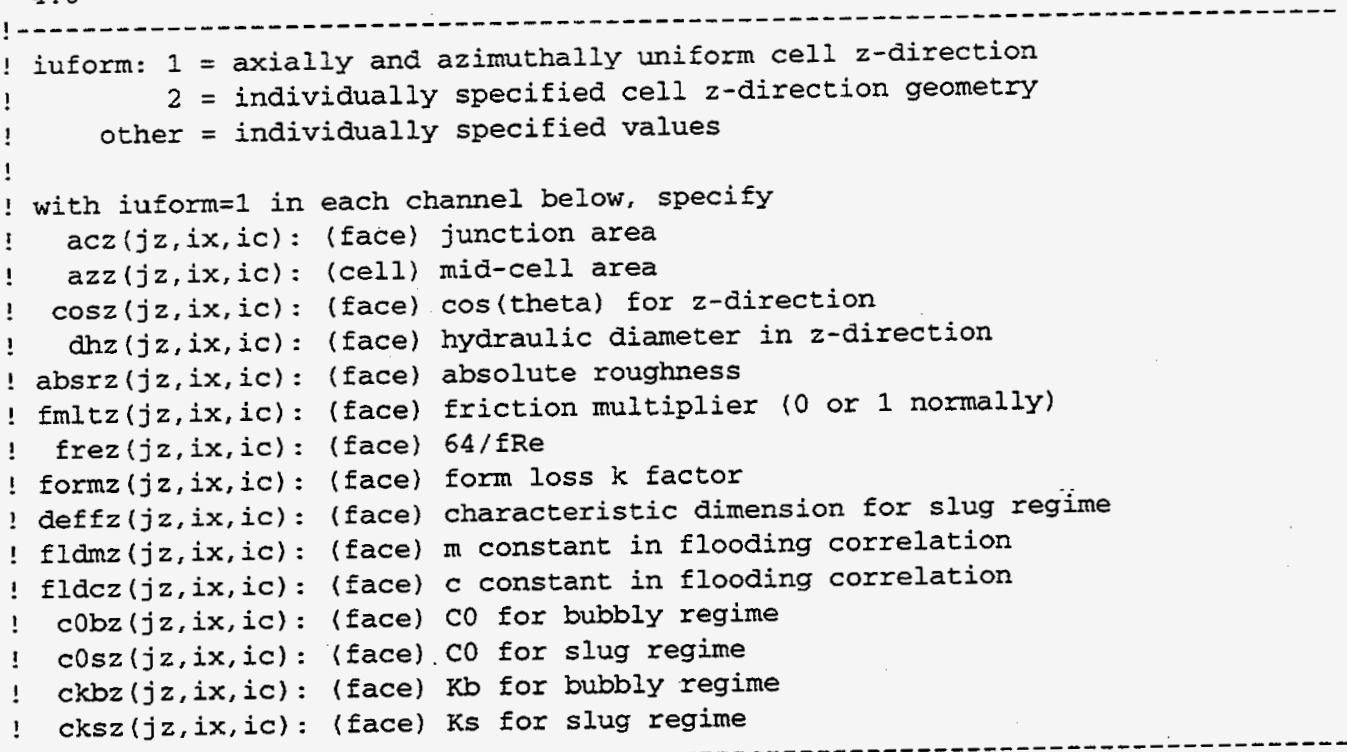

/CHANNEL $1 /$

/CHANNEL 1 Z GEOMETRY/

! iuform

1

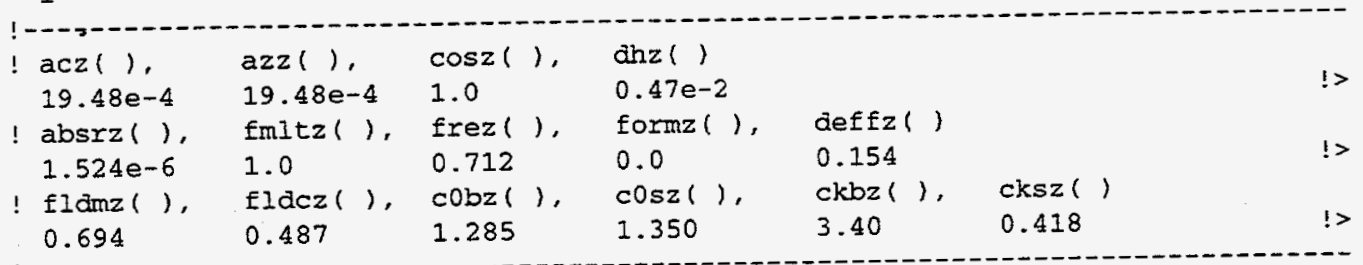

! CHANNEL 21

/CHANNEL 2 \& GEOMETRY,

! iuform

1

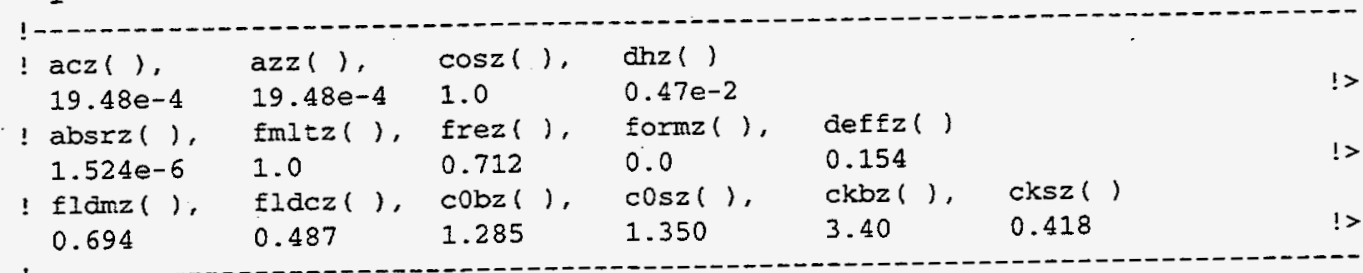

/CHANNEI 3 / 
WESTINGHOUSE SAVANNAH RIVER COMPANY

APT BLANKET SAFETY ANALYSIS: (DOWNFLOW THROUGH A FRONT LATERAL ROW-1 MODULE)
Report:

Section:

Date:

Page:
WSRC-TR-98-0163

Appendix B

$07 / 29 / 98$

14 of 20

\section{/CFANNEL 3 \& GEOMETRY/}

! iuform

1

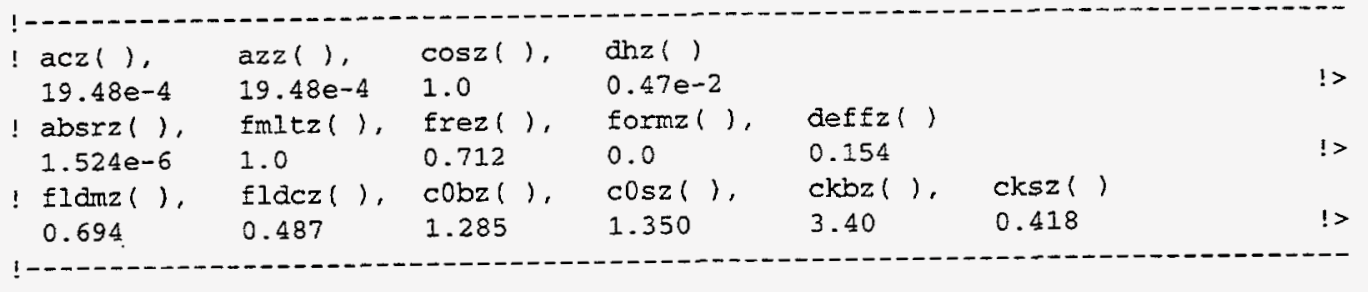

/CHANNET $4 /$

/CHANNEL $4 \mathrm{Z}$ GEOMETRY/

! iuform

1

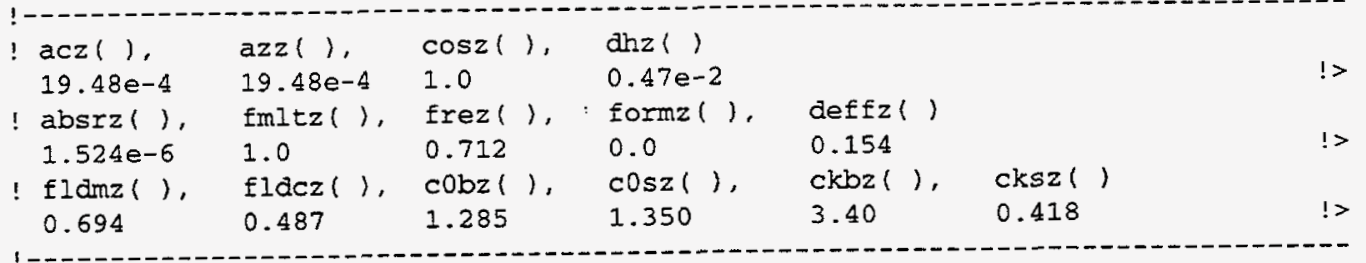

ICHANNEL $5 /$

1 - CHANNEI $5 \mathrm{Z}$ GEOMETRY

! iuform

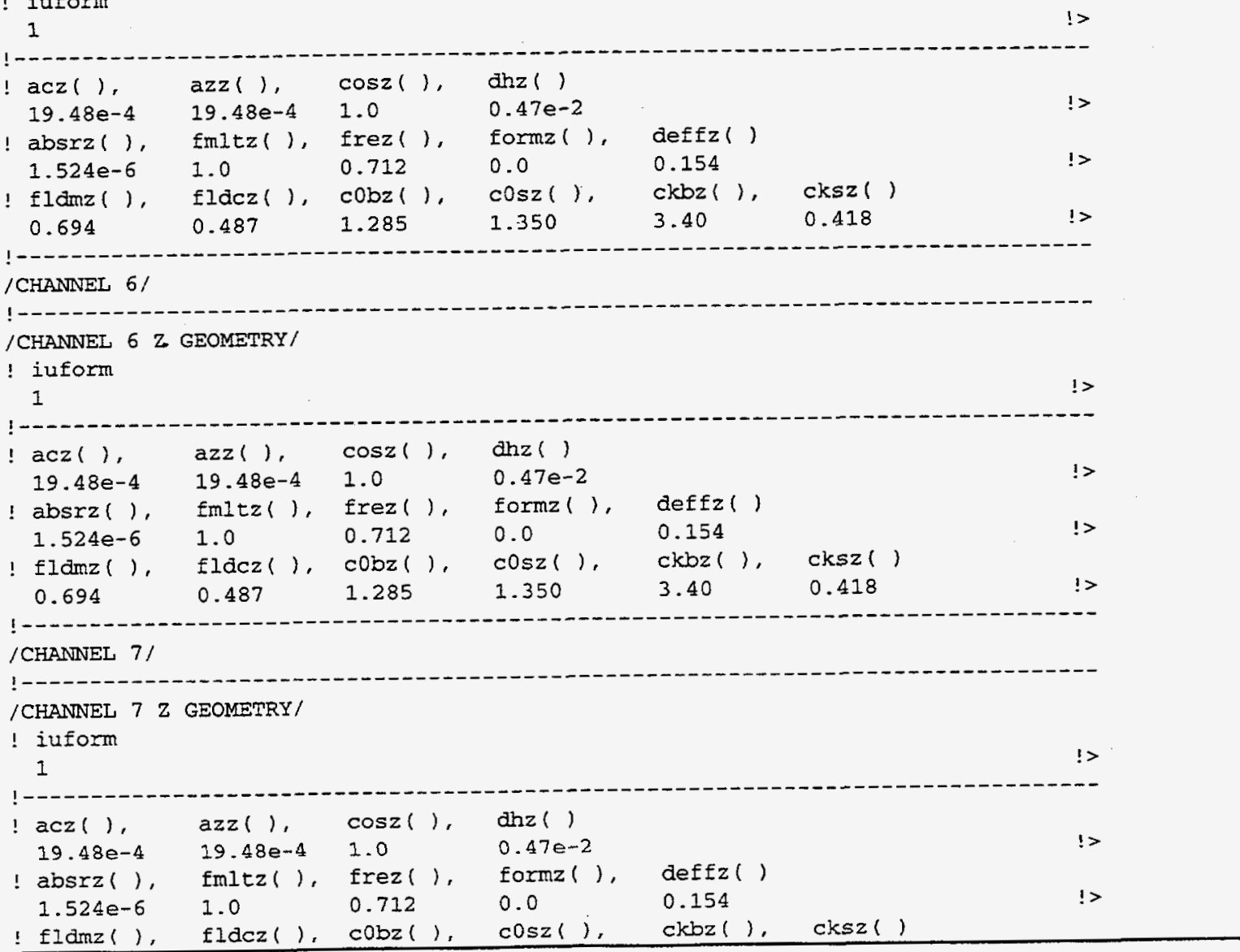




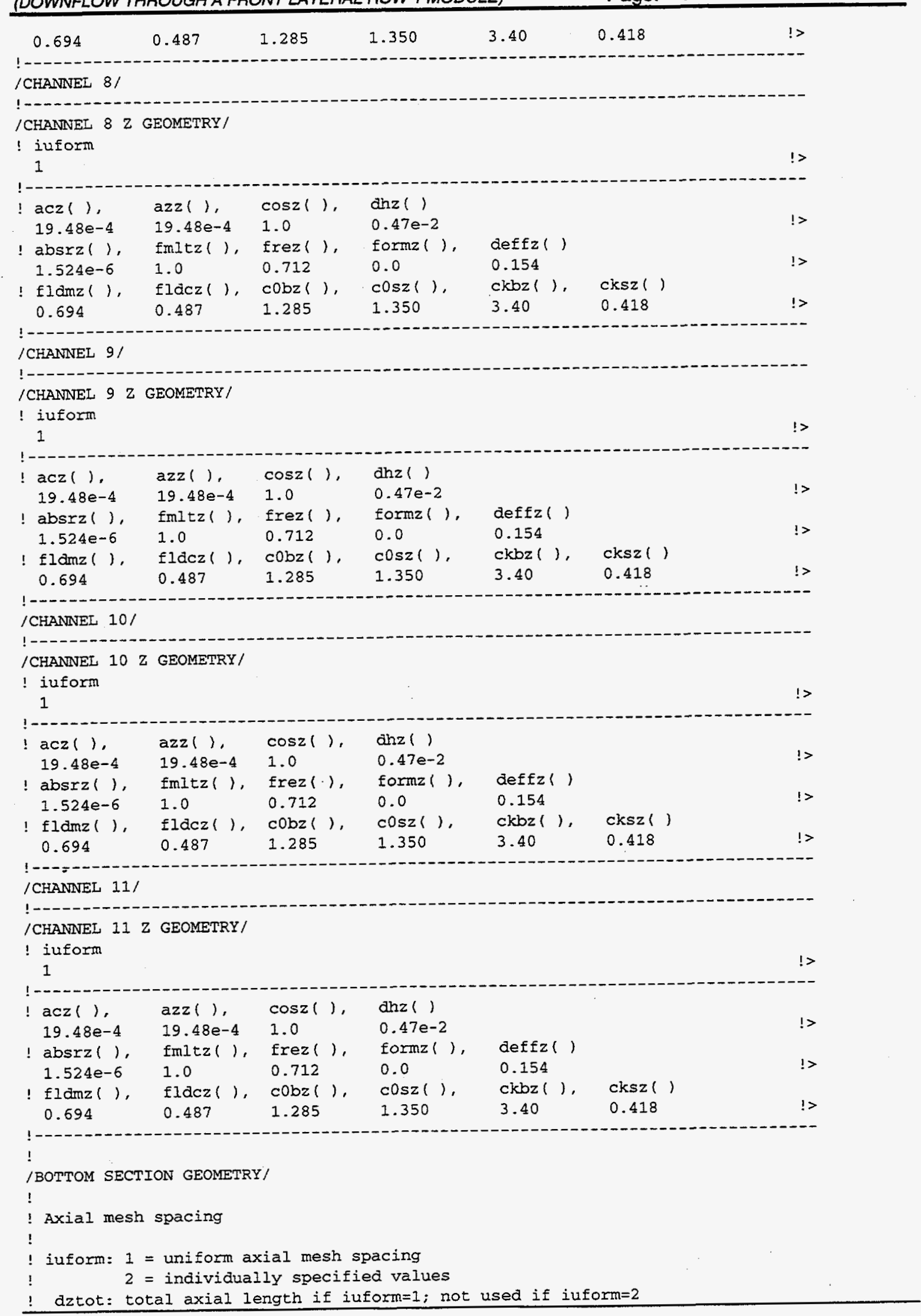


! (must be specified however)

!dzt $(j z)$ : axial cell lengths if iuform $=2$

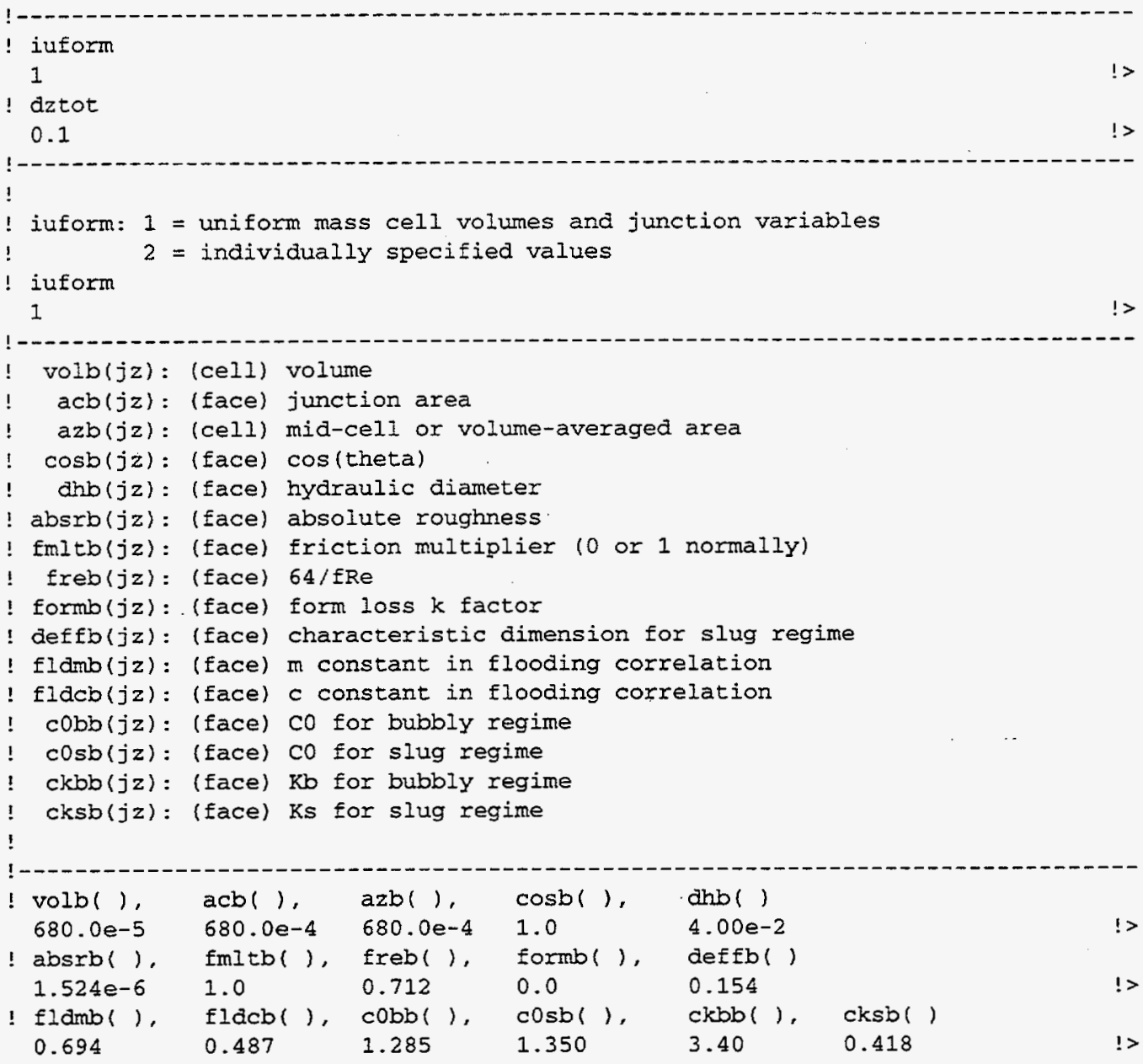

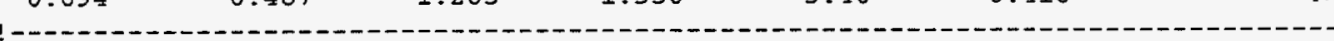

!

/BOTTOM BOUNDARY CELL: TANK BOTTOM VOLUME AND AREA/

! voltb: tank bottom volume

! actb: tank bottom mid-cell area

! voltb, actb

$680.0 e-5 \quad 680.0 e-4$

/BOUNDARY CONDITION INPUT SECTION/

/INLET PLENUM (TOP)/

! ppl0: multiplier to $P$ transient profile

ippl: P transient identifier

! alppl0: multiplier to alpha transient profile

ialpl: alpha transient identifier

tfpl0: multiplier to Tf transient profile

itfpl: Tf transient identifier

tgpl0: multiplier to Tg transient profile

itgpl: Tg transient identifier

xapl0: multiplier to xa transient profile

ixapl: Xa transient identifier

pplo, ippl

$720000.0 \quad 1 \quad !>$ 


$\begin{array}{ll}\text { alppl0, } & \text { ialpl } \\ 1.0 & 4 \\ ! \text { tf010, } & \text { itfpl } \\ 53.0 & 1 \\ ! \text { tgpl0, } & \text { itgpl } \\ 53.0 & 1 \\ ! \text { xapl0, } & \text { ixapl } \\ 0.9 & 1\end{array}$

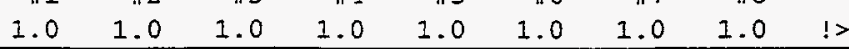


/CRITERIA CHECKING TIME/

! time to begin criteria checking, sec

!

! tcrito

0.0

!>

! POWER INPUT

!

/POWER PROFILE SPLINE POINTERS/

! DECAY HEAT TRANSIENT

$2 \quad !>$

!

/AXIAL SPLINE POINTERS AND TIMES/

$\begin{array}{llll}3 & 0.0 & 3 & 300.00\end{array}$

!

/TRANSIENT DATA SET INPUT SECTION/

/DATA SET NUMBER $1 /$

! enter data set label below

! $-\cdots$

data set 1 - UNIFORM

! itype: 1 = linear spline

itype: 1 = cubic spline

! $x, y$ : data pairs

! itype

$\begin{array}{cll} & 1 & !> \\ ! x(\text { ipt }), & y(\text { ipt }) & \text { ipt=1, npts } \\ 0.0 & 1.0 & !> \\ 5.0 & 1.0 & !> \\ 100.0 & 1.0 & !>\end{array}$

/DATA SET NUMBER $2 /$

data set 2 - DECAY POWER SHAPE

! itype

$1 \quad !>$

! $x$ (ipt), $y$ (ipt) ipt=1, npts

$0.01 .0 \quad !>$

$1.0 \quad 1.0 \quad$ !

$10.0 \quad 1.0 \quad 1>$

$100.0 \quad 1.0 \quad !>$

!-

/DATA SET NUMBER 3/

data set 3 - NON-UNIFORM AXIAL POWER PROFILE

! itype

! x(ipt), $\begin{array}{ll}1 & !> \\ \text { (ipt) } & \text { ipt=1,npts }\end{array}$

$0.00000 \quad 0.08000$

$0.14286 \quad 0.10507$

$0.28571 \quad 0.17903$

$0.42857 \quad 0.29817$

$0.57143 \quad 0.45651$

$0.71429 \quad 0.64612$

$0.85714 \quad 0.85748$

$1.00000 \quad 1.08000$

$1.14286 \quad 1.30252$

$1.28571 \quad 1.51388$ 

$1.42857 \quad 1.70349$
$1.57143 \quad 1.86183$
$1.71429 \quad 1.98097$
$1.85714 \quad 2.05493$
$2.00000 \quad 2.08000$
$2.14286 \quad 2.05493$
$2.28571 \quad 1.98097$
$2.42857 \quad 1.86183$
$2.57143 \quad 1.70349$
$2.71429 \quad 1.51388$
$2.85714 \quad 1.30252$
$3.00000 \quad 1.08000$
$3.14286 \quad 0.85748$
$3.28571 \quad 0.64612$
$3.42857 \quad 0.45651$
$3.57143 \quad 0.29817$
$3.71429 \quad 0.17903$
$3.85714 \quad 0.10507$
$4.00000 \quad 0.08000$

IDATA SET NUMBER $4 /$

! enter data set label below

! -

data set 4 - VOID

! itype: 1 = linear spline

$! \quad 0=$ cubic spline

! $x, y$ : data pairs

! itype

1 i>

! $x$ (ipt), $y$ (ipt) $\quad$ ipt $=1$, npts

$0.0 \quad 0.0 \quad$ i>

$5.0 \quad 0.0 \quad 1>$

$100.0 \quad 0.0 \quad 1>$ 
